Portland State University

PDXScholar

Winter 3-23-2018

\title{
Using the Syrian Civil War to Measure Hierarchy: Regional Power Transition in the Middle East
}

Eric Michael Clary

Portland State University

Follow this and additional works at: https://pdxscholar.library.pdx.edu/open_access_etds

Part of the International Relations Commons

Let us know how access to this document benefits you.

\section{Recommended Citation}

Clary, Eric Michael, "Using the Syrian Civil War to Measure Hierarchy: Regional Power Transition in the Middle East" (2018). Dissertations and Theses. Paper 4359.

https://doi.org/10.15760/etd.6252

This Thesis is brought to you for free and open access. It has been accepted for inclusion in Dissertations and Theses by an authorized administrator of PDXScholar. Please contact us if we can make this document more accessible: pdxscholar@pdx.edu. 
Using the Syrian Civil War To Measure Hierarchy:

Regional Power Transition in the Middle East

by

Eric Michael Clary

A thesis submitted in partial fulfillment of the requirements for the degree of

Master of Science

in

Political Science

Thesis Committee:

Birol Ali Yeşilada, Chair

David Kinsella

Shawn Smallman

Portland State University

2018 


\section{Abstract}

In 2018, the Syrian Civil War will enter into its ninth year of conflict. From an international relations perspective there are few, if any, studies on state actors in regional sub-state systems. What can an intrastate conflict teach us about future dynamics of the regional interstate hierarchy? It is worthwhile to examine The Syrian Civil War for three reasons. First, Syria lies in the heart of the Middle East lending proximity to regional actors. Second, the breakdown of order in Syria represents a microcosm of the global anarchic environment. Third, Syrian Civil War is an intrastate war that encapsulates both state and non-state actors. This paper intends to provide a clear regional hierarchal analysis with future possibilities and perspectives.

For the last century realism then neorealism dominated the field of international relations, yet they are unfit theories for analyzing the Middle East's hierarchy. To address anomalies realists and neorealists incorporated preference and satisfaction, which undermined the core tenets of their theories. Power Transition Theory (PTT) incorporates satisfaction while maintaining structural organization. The addition of power and satisfaction give PTT the necessary tools to assess regional hierarchies and estimate the likelihood of conflict. Using this PTT theoretical framework I will assess the global hierarchy, the status quo set by the United States, and Syria's relation to the status quo. I then provide a synopsis of the Syrian Civil War to contextualize the actors and dyadic comparisons between actors before and after the Iranian-Russian-Syrian victory in Aleppo. The dyadic comparison indicates power and satisfaction among interested parties and if they change during the course of the conflict. 
Conclusions indicate that the actors and the environment in the Syrian theater are suitable for Power Transition Theory and the data acquired by researching the Syrian Civil War affirms Yeşilada and Tanrikulu's assessment that Russia tops the Middle East's hierarchy with Turkey and Iran following at near parity. The findings reveal the veracity of Lemke's claim that PTT can be utilized for intrastate conflict. The findings substantiate my claim that intrastate conflict can inform us of a region's hierarchy. 


\section{Acknowledgments}

I am very grateful to Dr. Birol Ali Yeşilada, who assisted my efforts at Portland State University. He consistently took the necessary time to provide valuable feedback and guidance. Dr. Yeşilada encouraged me to push myself even when it meant more work at his expense. Dr. Yeşilada's grasp on Middle East politics and history proved invaluable to my regional focus. I want to thank Dr. David Kinsella for sitting on my committee. Dr. Kinsella possesses a thorough command of international relations theory and his aptitude for teaching aided my conceptual understanding of its complexities. I was also very privileged to assist Dr. Shawn Smallman. Dr. Smallman was very appreciative of my work, and I of his. Dr. Smallman is an excellent professor and a gifted writer. 


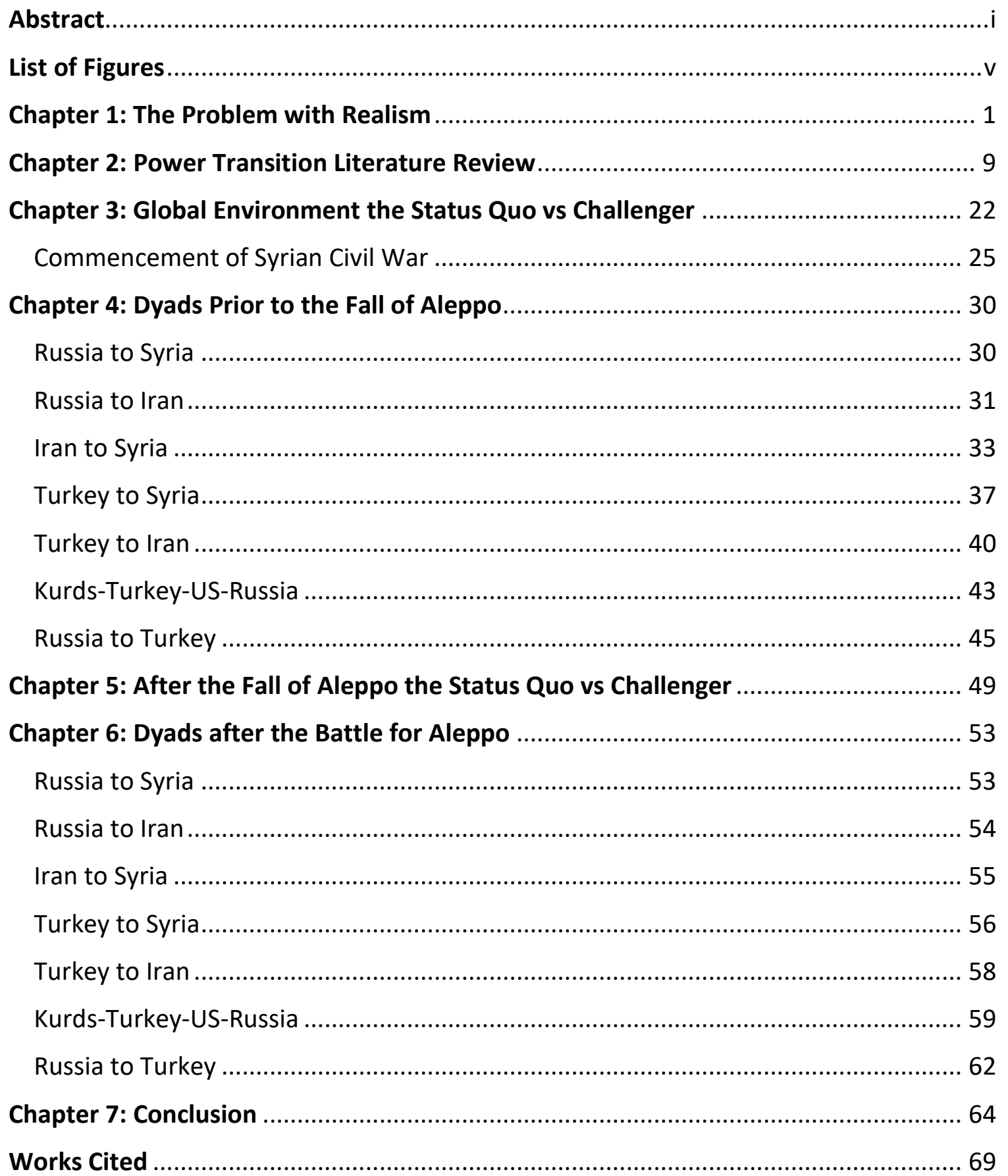




\section{List of Figures}

Figure 1 Global Power Hierarchy taken from (Tammen, Kugler, \& Lemke, 2011) ........... 11

Figure 2 Purchasing Power Parity data gathered from World Bank 9/22/2017 ............ 15

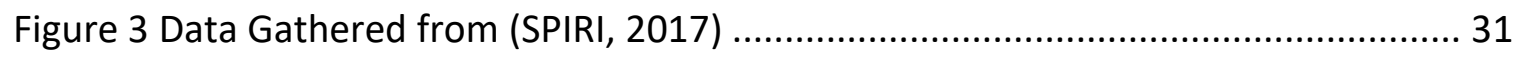

Figure 4 Map amended from original found at Stratfor (2017) ................................. 52

Figure 5 Middle East Hierarchy updated from (Tammen, Kugler, \& Lemke, 2011) ......... 65 


\section{Chapter 1: The Problem with Realism}

For the last century, realism has been held in high regards among international relations (IR) theorists but realism lags in predictive qualities and explanatory value. Efforts to correct this resulted in hybrids of traditional realism known as neorealism, which often provides never-ending streams of theories contradict its core tenets. Realism's origins begin in the fifth century B.C.E during the Peloponnesian War. Thucydides records the famous aphorism, "Might makes right," whereby Athens orders the submission of Melians to Athenian rule. The Melians refuse and men of military age are killed and the women and children or enslaved. According to Kinsella, Russett, \& Starr, the Melians failed to understand that "Might makes right" is not Athenian policy but "a law of nature" (Kinsella, Russett, \& Starr, 2013, p. 40). This, perhaps, remains the most salient point realism offers. Two and a half millennia have passed and leading realist Mearsheimer states the same thing, "International politics is synonymous with power politics" (Mearsheimer, 2006, p. 72).

Legro \& Moravcsik claim that realist theory stands on three core assumptions (Legro \& Moravcsik, 1999, pp. 12-17). One, the environment is anarchical and the units of analysis are unitary. States comprise the international system but no cohesive authority regulates state behaviors. Two, states' interests are fixed and conflictual. To be clear, Dahl famously defined power as, " $A$ 's ability to get B to do something that B

would not otherwise do" (Kinsella, Russett, \& Starr, 2013, p. 71). In the IR world, the “A, B" units of analysis are states. Human actors constitute states which behave according to natural law. For realists, humanity is "self-interested, even selfish, and seek to 
dominate others. They cannot be depended on to cooperate, and if they do cooperate, they will stop when it no longer serves their immediate interests" (Kinsella, Russett, \& Starr, 2013, p. 22). States must maximize their power to avoid acting in the interests of others. Three, states' bargaining power reflects their material wealth. "Realism stresses the ability of states, absent a common international sovereign, to coerce or bribe their counterparts" (Legro \& Moravcsik, 1999, p. 17).

A system composed of self-interested actors in an anarchic environment is often referred to as a "self-help" system (Kinsella, Russett, \& Starr, 2013, p. 23). In a self-help system maintaining equilibrium, or relative power capabilities, prevents war. This thought stems from a structural concept known as the security dilemma, whereby "Any country that improves its position in the global balance of power does so at the expense of other states, which lose relative power" (Mearsheimer, 2006, p. 75) forcing states to join a coalition of other states or increase power endogenously ${ }^{1}$. When states are at equilibrium it is known as the balance of power; the idea that "no single state or coalition of states dominates the international system" (Kinsella, Russett, \& Starr, 2013, p. 79). According to the theory, if nations are balanced the system is most likely to be at peace.

Neorealism is much harder to define as neorealism inherits many of the same features as realism, but compensates where realism falls short. Brooks observes, "All

\footnotetext{
${ }^{1}$ According to Mearsheimer, power is "based on the material capabilities that a state controls" (Mearsheimer, 2006, p. 72). Material capabilities must include military assets like nuclear weapons and military hardware, and latent power like economic power and a productive population (Mearsheimer, 2006, pp. 72-73).
} 
realists agree that military security is the state's prime responsibility and that relative military capacity ultimately depends on a state's productive base" (Brooks, 1997, p. 446). The incorporation of an economic base divides realists and neorealists on two core issues, natural law and the decision-making process. Brooks explains that, "Beyond the human nature arguments of classical realism; neorealists simply swap one aspect of human nature (aggression) for another (fear)" (Brooks, 1997, pp. 449-540). This defensive approach affects the decision-making process introducing probability versus possibility, and military preparedness versus economic capacity (Brooks, 1997, p. 446). However, Realism and neorealism's lack of satisfaction in anarchic environment necessarily means, "A rational state never lets down its guard: states adopt a worst-case perspective and always aim to balance the military capabilities of potential aggressors" (Brooks, 1997, p. 448). The notion that the balance of power guarantees peace was given law-like status. But, scholars, notably the founder of power transition theory (PTT), A.F. K Organski, question the veracity of the balance of power theory. Organski found that, "The popularity of the balance of power theory derives not only from general desire for a law of politics but also from the fact that this theory purports to describe processes that are automatic" (Organski, 1958, p. 283). Realism's formula sought to mirror the state of equilibrium. Challenging the realist model ${ }^{2}$, Organski simply asks, "If the balance of power is a permanent law, how can the balance disappear?" (Organski, 1958, p. 285). Organski identifies two problematic premises

\footnotetext{
${ }^{2}$ During Pax Americana and Pax Britannica nations could have balanced against them but did not.
} 
associated with the balance of power theory. First, nations are not static-they are capable of endogenous growth (Organski, 1958, p. 288). It was previously believed that nations resembled a chess pieces where, "The pieces are of a given power, but they are skillfully manipulated in various ways as the game changed" (Organski, 1958, p. 289). Organski argues the modern phenomena of nationalism and industrialism could increase a nation's power. Organski realized that both phenomena did not merely create larger units but a new kind of unit where, "Citizens can be mobilized into an awesome instrument of power by the ruler who is skilled in new techniques" (Organski, 1958, p. 289). Nationalism and industrialism rallied citizens to fight on behalf of the homeland spurred them to build heavy industry to manufacture armaments necessary in modern warfare. Napoleon Bonaparte is often cited as the first to capitalize on these to mechanisms.

Second, it is a false notion that nations do not maintain permanent ties, but "move about freely, motivated primarily by considerations of power" (Organski, 1958, p. 288). States have increased ties since the industrial revolution because of trade.

Oraganski claims the Anglo-French- American coalition was only, "Vaguely understood in the days before WWI" (Organski, 1958, p. 290). The United States sided with Western Europe during WWI, later in WWII, and again committed to Western Europe during the Cold War. Organski cites British and French relations after the Napoleonic Wars as a prime example, stating, "England and France were firmly tied together. Failure to understand this was one of the most serious blunder Germany ever made" (Organski, 1958, p. 290). In special relationships, built on common culture and understanding, 
satisfied nations can rise peacefully, overtake a dominate nation, and become heir of the established structural paradigm. This occurred when the United States peaceful surpassed the British Empire at the end of the nineteenth century (Tammen, et al., 2000 , p. 50). Though the balance of power changed, the United Kingdom did not even threaten the United States because of British economic interests in the US (Tammen, et al., 2000, p. 50). Furthermore, the rise in democratic countries meant that legalities prohibited many nations from changing alliances (Organski, 1958, p. 290). For example, Article I of the U.S. Constitution grants congress the power to declare war and Article VI makes treaties "supreme Law of the Land". Conflicts with the balance of power theory coupled with additional approaches to human nature have led to a plethora of hyphenated realisms ${ }^{3}$.

In "Is Anybody Still a Realist?" authors Legro and Moravcsik insist that neorealism incorporates liberalism, institutionalism, and epistemic theories to accommodate, "empirical anomalies", such as law, ideology, and economic integration at the cost of core realist principles (Legro \& Moravcsik, 1999, p. 6). Reducing neorealism to the core tenets of, the international environment is anarchic and states utilize rational choice theory, means that, "Minimal realism [hybrids of neorealism] broadens realism so far that it is now consistent with any influence on rational state

\footnotetext{
3 "[Most contemporary scholars]recommend that we synthesize theories by automatically considering realism first (with preferences assumed to be invariant) and then introducing competing theories of preference or belief change as needed to explain residual variance: 'Liberalism ... makes sense ... within the explanatory constraints imposed by realism' or "When realist theories are found wanting, we should supplement them with new culturalist theories.' This conventional procedure, we have argued in detail elsewhere, lacks any coherent methodological or theoretical justification (Legro \& Moravcsik, 1999, pp. 51-52).
} 
behavior" (Legro \& Moravcsik, 1999, p. 7). While Legro and Moravcsik do not question the veracity of competing realisms, they do object to labeling them as traditional realism. But, where specifically does traditional realism fall short? Legro and Moravcsik do not deny that the global environment is an anarchic system composed of unitary actors but they critique the second two core realist assumptions: states' interests are fixed and conflictual, and states' bargaining power is reflected by their material wealth. First, if states' interests are fixed and conflictual, it excludes positive sum relationships, defensive realism (where states prefer security), and harmonious state policies and strategies (not to be confused with harmonious interests) (Legro \& Moravcsik, 1999, pp. 15-16). A traditional realist like Morgenthau emphasizes power as the end goal, while a defensive neorealist like Waltz claims states' interests can range from mere survival to uni-polarity. Brooks argues that the crux of the realist schism hinges on, "Whether states are conditioned by the mere possibility of conflict or, alternatively, make decisions based on the probability of aggression $4 "$ (Brooks, 1997, p. 446). In all cases, realism is "concerned primarily with the determinants of distributive bargaining among states" (Legro \& Moravcsik, 1999, p. 16). Mearsheimer asserts structural realism ignores, "Cultural differences among states as well as differences in regime type, mainly because the international system creates the same basic incentives for all great powers" (Mearsheimer, 2006, p. 72). Mearsheimer's statement is odd, in that structural realists emphasize power, yet they are indifferent on

\footnotetext{
${ }^{4}$ Brooks' analysis is divergence between neorealism and postclassical realism, a more elusive term. But, the question of probability versus possibility remains true for traditional realism.
} 
where power originates. If power and material capabilities are the only things considered, then Legro and Moravcsik assert, that what is missing are assumptions about the source and resolution of conflict (Legro \& Moravcsik, 1999, p. 21).

Second, if bargaining power is reflective of material capabilities and no other factors are considered (preferences, beliefs, and international institutions), then variations are difficult to explain (Legro \& Moravcsik, 1999, pp. 16-17). If we assume that states are unitary and hold conflicting interests, then we characterize the agents but not the environment and "describe a world of constant background conditions" (Legro \& Moravcsik, 1999, p. 17). In a rebuttal to realism Moravcsik clarifies his point stating,

Liberal theory reverses this assumption: Variation in ends, not means, matters, most. Realists and institutionalists, as well as formal theorists who seek to integrate the two, criticize this core liberal assumption because it appears at first glance to rest on that Waltz terms 'reductionist' rather than a 'systemic' understanding of IR (Moravcsik, 1997, p. 522).

To Moravcsik, liberal theory is not reductionist because, "State preferences may reflect patterns of transnational societal interaction", and, "National leaders must always think systemically about their position within a structure composed of the preferences of other states" (Moravcsik, 1997, pp. 522-23). For example, during Germany's rapid rise in the 1930s, Schweller finds that compatibility of political goals not imbalances of power determined alignment decisions (Legro \& Moravcsik, 1999, p. 30). Schweller's contribution of "variation in state preference" takes away the coherence and distinctiveness of realism (Legro \& Moravcsik, 1999, p. 30). In all scenarios, states' 
interests are no longer fixed and national policies may vary within the system leading to different behavioral patterns.

Most international relations scholars would agree that there are obvious incentives to being a hegemon, yet realists have previously neglected endogenous growth and the nature of the orders created by dominant powers. What Moravcsik argues is that for a theory to be of any value it must possess explanatory power. To their detriment, realists increasingly finds themselves incorporating liberalism, institutionalism, and epistemic theories to explain occurrences in the international community. Indeed, realism lacks preference and satisfaction, as Moravcsik observes, nations rarely mortgage their future for foreign policy. "Few wars are total, few peaces Carthaginian" (Moravcsik, 1997, p. 524). 


\section{Chapter 2: Power Transition Literature Review}

In an effort to lend depth and clarity to international relations, Power Transition

Theory (PTT) scholars contend that the theory is, "Neither realist nor idealist", clarifying, "It is structural, yet dynamic since it recognizes that policy interests are at the core of all disputes" (Tammen, et al., 2000, p. 6). Accompanying the theoretical framework are two recent contributions to the field of PTT that will aid in this paper's overall analysis: one, Yeşilada and Tanrikulu (2016) provide a current hierarchal assessment of the Middle East's regional powers, and two, Lemke (2008) contributes a theoretical adaption to the method of analyses.

To begin, PTT incorporates two core elements, power and satisfaction, into a hierarchal system where nations fulfill roles (Yeşilada \& Tanrıkulu, 2016, p. 26). First, using Dahl's "power example", we might ask, what must state " $A$ " have to make state " $\mathrm{B}$ " do what it would otherwise not do? Remembering that coercion may not be a state's preference, theorists have incorporated the following components, when combined, are a function indicating a country's power ${ }^{5}$ (Tammen, et al., 2000, p. 15).

1) Gross domestic product $(G D P)^{6}$ is the most accurate measurement to gauge a nation's economic performance. The importance here is that money is fungible and a vibrant economy is necessary for building a capable military. The endogenous growth theory demonstrates that states can develop wealth

\footnotetext{
${ }^{5}$ According to PT theorists, "Extensive tests show that this measure accurately accounts for the outcome of conflicts waged among fully committed competitors" (Tammen, et al., 2000, p. 16)

${ }^{6}$ Is defined as "the monetary value of all the finished goods and services produced within a country's borders in a specific time period" (Investopedia).
} 
domestically which means they can gain power. The importance of economics is underlined by PTT's assumption that there is, "No distinction between security and economics" (Tammen, et al., 2000, p. 107). Organski argues, "It was England's factories, not her diplomats, that let her dominate the nineteenthcentury world" (Organski, 1958, p. 289).

2) PTT scholars argue that population is "sine qua non" to achieve great power status (Tammen, et al., 2000, p. 18). Simply put economies are built upon a productive citizenry, but the key word here is productive. An uneducated and unhealthy population is often a liability to national power rather than an asset.

3) Political capacity is the government's ability to govern and extract resources from their populations (Tammen, et al., 2000, p. 20). Effective governments need resources to achieve their objectives (Tammen, Kugler, \& Lemke, 2011, p. 4). Kugler and Tammen describe political capacity as having two components: extraction and allocation of resources. Arbetman and Johnson summarize political extraction ${ }^{7}$ as taxation (Arbetman-Rabinowitz, Group, \& Johnson, 2007, p. 4) and allocation, "Deals with the optimal use of public resources to advance national growth" (Tammen, Kugler, \& Lemke, 2011, p. 4).

\footnotetext{
${ }^{7}$ Taxation "represents willingness on the part of the population (or enforcement ability on the part of the government) to transfer resources from private individuals to the government. This resource transfer is the bridge between politics and money; taxation demonstrates an endorsement or at least acceptance of a government by the population" (Arbetman-Rabinowitz, Group, \& Johnson , 2007, p. 4)
} 
For the purposes of this paper ${ }^{8}$, it is important to include Kim's contribution to Power Transition Theory. PTT previously assessed power dyadically, but Kim (1989) considers alliances as part of a nation's power potential. To estimate the likelihood of war, Kim's calculations incorporate utility expectations between states but uses allied contributions as a metric. "Thus, for Kim 'parity' does not refer strictly to the calculations of relative power between states A and B. Rather, for Kim 'parity' exists when the capabilities of state A plus those of its allies, are roughly equal to the capabilities of state B plus those of its allies" (Tammen, Kugler, \& Lemke, 2011, p. 16).

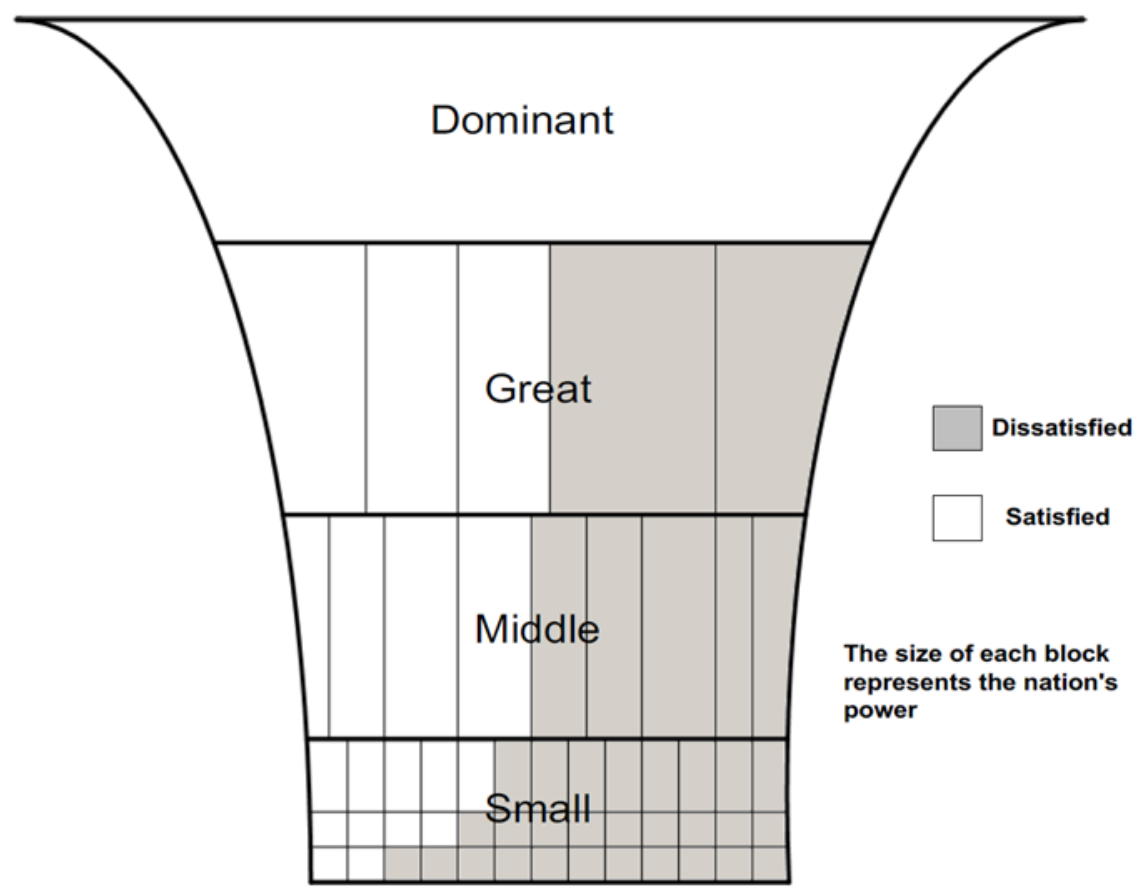

Figure 1 Global Power Hierarchy

Figure 1 Global Power Hierarchy taken from (Tammen, Kugler, \& Lemke, 2011)

\footnotetext{
8 This paper analyzes the Middle East therefore it is important to note that "there is more reason and opportunity for global powers to intervene in those other regions" (Tammen, Kugler, \& Lemke, 2011, p. 11).
} 
The second element PTT considers is satisfaction. The global order is divided into hierarchies of satisfied and dissatisfied nations. In a system of overwhelming preponderance, the dominant nation and its allies can impose a set of rules that are consistent with their preferences (Tammen, Kugler, \& Lemke, p. 10). Figure Nations are organized in a hierarchical system where they fulfill certain roles within the status quo, managed by the preponderant power. Power transition theorists insist that, "Dominant powers in asymmetric hierarchies allow supporters of the status quo to challenge core propositions, but reject dramatic changes in rules demanded by the dissatisfied" (Tammen, Kugler, \& Lemke, 2011, p. 12). Dissatisfied nations object to the international framework's rules and norms established by the dominant power. A dissatisfied nation wants to change the status quo and establish a new order to its liking (Tammen, et al., 2000, p. 9). Examining satisfaction, Yeşilada and Tanrikulu argue that a country's value system is a significant variable that indicates the probability of integration or conflict with another nation- i.e., the likelihood of forming a status quo. Nations with differing value systems are unlikely to agree upon the rules and norms that give order to a status quo relationship.

In Yeşilada and Tanrikulu's study, a nation's value system is ascertained through data collected by the World Values Survey (WVS). The data is then analyzed through tenets of human development theory (HDT). HDT asserts that economic progress results in significant changes to human values, a claim supported by empirical evidence (Yeşilada \& Tanrıkulu, 2016, pp. 26-27). When changes in values occur, national policies often follow. But how do scholars determine which variables are significant? 
In this regard Inglehart and Welzel provide some direction through their two compound variables that capture more than 78 percent of cross-national variance in social change across the world. These variables capture individual's relative religiosity and social values along two dimensions: traditional-secular and materialist-post materialist values (Yeşilada \& Tanrıkulu, 2016, p. 27).

Yeşilada \& Tanrıkulu agree that religiosity and social values indicate a nation's proclivities toward satisfaction or dissatisfaction. They conclude that, "Convergence [on values] has a greater impact on integration than power" (Yeşilada \& Tanrıkulu, 2016, p. 37). Articulated differently, preference not power is more likely to determine convergence. Though power is less of a factor, weak states are more likely to conform to the hegemon's value system (Yeşilada \& Tanrıkulu, 2016, p. 37).

Some may ask where liberalism falls in the PTT paradigm? If were are to utilize Moravcsik's understanding of liberalism, it is compatible with PTT. To recall, Moravcsik contends liberal mechanisms are the ends not the means. A dominant power can choose to establish a status quo using liberal mechanisms and, in fact, the United States has. Yeşilada and Tanrıkulu's usage of HDT assumes that liberal mechanisms lead to post-modern values which further promotes integration.

Structurally, two conditions in the states' systemic hierarchy increase the probability of war. The first condition, parity, is defined as a potential challenger to the dominant power. Once a great nation develops more than 80 percent of the resources possessed by the dominant nation, it falls within power parity. A dominant power, therefore, exceeds the resources of the next most powerful nation by 20 percent (Tammen, et al., 2000, p. 21). The next condition is overtaking. Overtaking occurs when a great nation develops resources at a faster rate than the dominant nation, eventually 
reaching parity. In this scenario the dominant nation becomes a defender of the status quo while the rising great power becomes a challenger. Overtaking lasts until the challenger nation surpasses the defender by 20 percent in resources (Tammen, et al., 2000 , p. 21). The probability of conflict increases greatly when a dissatisfied nation is in the process of overtaking. If a rising dissatisfied nation reaches power parity with the global power, the probability of conflict is at its highest. Power Transition Theory (PTT) differs from traditional realism by asserting that the balancing of power does not bring peace but increases the frequencies and intensify of modern warfare (Organski, 1958, p. 299). The core elements of parity and satisfaction are effective predictors of conflict not just at the global level, but also at the regional level.

Douglas Lemke extended the PTT paradigm to regional hierarchies, contributing, "Toward a general theory of world politics" (Tammen, Kugler, \& Lemke, 2011, p. 10). To paraphrase Power Transitions: Strategies for the 21st Century, regional hierarchies exist and function like the overall global hierarchy. However, regional hierarchs are subordinate to the overall global hierarchy (Tammen, et al., 2000, p. 65). The structural component of PTT comes from the global hierarch's ability to involve itself in regional disputes. "Global powers like the US, EU, Russia and soon China can directly intervene to alter outcomes in a region. But regional powers cannot effectively intervene in the global hierarchy" (Tammen, Kugler, \& Lemke, 2011, p. 11). Global powers rarely face direct challenges from regional actors making their regional intervention uncommon but possible (Tammen, et al., 2000, p. 65). In “Regional Power Transition and the Future of Turkey", Yeşilada and Tanrikulu assess the regional hierarchy of the Middle East in the 
PTT paradigm. To gauge a country's power, Yeşilada and Tanrikulu focus on per capita productivity and the relative share of a country's regional economic power (Country ' $A$ ' $s$ ' annual economy stacked against the sum total of the annual economies of regional countries). Yeşilada and Tanrikulu confirm that presently Iran and Turkey are within power parity. The findings reveal that Russia is the region's preponderant actor but will be challenged by Turkey within ten to fifteen years (Yeşilada \& Tanrıkulu, 2016, pp. 27, 37). Figure 2 uses purchasing power parity to reach similar conclusions.

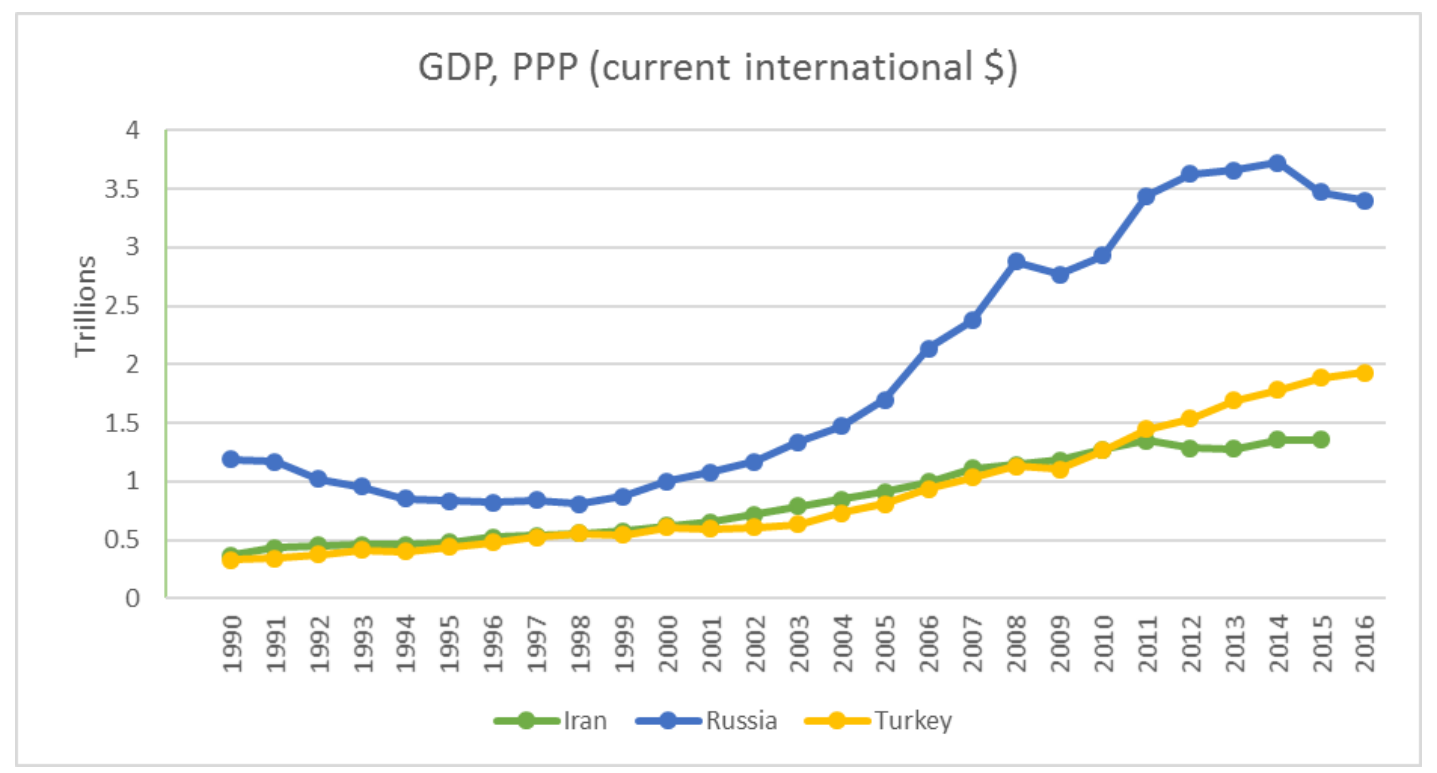

Figure 2 Purchasing Power Parity data gathered from World Bank 9/22/2017

In regards to satisfaction, the WVS doesn't maintain data on Iran, but the Iranian government's revolutionary model likely places them at odds with the predominantly Sunni secular Turkish republic. As unsatisfied actors, Iran and Turkey will likely compete for regional power and influence leading to "conflictual relations" (p. 37). Similarly, relations between Turkey and Russia will likely become conflictual within twenty years, 
an estimate obtained from relative power assessments and dissatisfaction (Yeşilada \& Tanrıkulu, 2016, p. 30).

But, where or on what issues would Russia conflict with Turkey? In other words, why is Russia considered part of the Middle East's regional hierarch? Tammen, Kugler, and Lemke state that, "Conflicts with Muslims within Russia and across former Soviet central Asia, and given Russia's role in the supply of oil to world markets, the Middle East might be the most likely re-direction for Russian foreign policy interests" (Tammen, et al., 2000, p. 23). In 2006, Yeşilada, Efird, and Noordijk emphasize the potential for conflict between Iran, Russia, and Turkey in the Caucuses noting, "The probability of such a scenario is quite high given Iran's pursuit of nuclear weapons and its dissatisfaction with Turkey's influence in Azerbaijan, Central Asia, and Georgia" (Yeşilada, Efird, \& Noordijk, 2006, p. 620). Likewise, Yeşilada and Tanrikulu observe, "Serious potential for gradually increasing conflict between Turkey and Iran that is consistent with their competition in the Caucasus and Northern Middle East" (Yeşilada \& Tanrıkulu, 2016, p. 30). Syria certainly qualifies as northern Middle East, lying just south of Caucuses, it borders Turkey and lies 380 miles from Russia and just 130 from $\operatorname{Iran}^{9}$ (see maps). Furthermore, Syria's role as an oil and gas transit nation, sandwiched between European consumers and Gulf and Caspian exporters, make it a strategic location. Umbach asserts, "Consumer nations are primarily interested in security of

\footnotetext{
9 "Proximity increases interactions between countries, forces countries to take each other seriously, and increases the potential for disputes" (Tammen, et al., 2000, p. 66). "Realists, including Stephen Walt and Stephen Krasner, identify the importance of geography, which affects both the utility of employing military force and access to raw materials" (Brooks, 1997, p. 456).
} 
supply, producer countries are more focused on security of demand from foreign markets" (Umbach, p. 3). Nations interested in securing supply or demand will naturally have an interest on the happenings in Syria. Somewhat related, the breakdown of sovereignty in the Syrian Civil War gives Iran, Russia, and Turkey an opportunity to maintain or challenge the status quo. Yeşilada and Tanrikulu's findings suggest it is likely that Iran and Turkey will be engaged in conflictual behaviors and I believe Syria is likely the theater for that conflict. Intrastate conflict is not approached using IR theory, however Lemke challenges this precedence and finds reason to believe that PTT has applicability to non-state actors.

Previously, IR divided quantitative studies between interstate and intrastate wars. Lemke attributes the division to two factors. First, there are, or were, different theories to analyze wars between, and within, states. Lemke points to realism's prominent position in the IR field and its use of large-n data to examine poles and power distributions in the international system (Cunningham \& Lemke, 2013, p. 610). Second, the field lacked data involving intrastate conflicts. Lemke stresses that the original Correlates of War (COW) excludes datasets on civil wars (Cunningham \& Lemke, 2013, p. 610), even though the victors of civil wars operate like states and emerge as liberated states $^{10}$.

Since the fall of the USSR, a noticeable increase of interest in conflicts involving non-state actors, known as "new wars", emerged (Cunningham \& Lemke, 2013, pp. 610-

\footnotetext{
${ }^{10}$ See Cunningham, D. E., \& Lemke, D. (2013). Combining Civil and Interstate Wars. International Organization, 609-627.
} 
11). Lemke identifies, "The 'new war's' scholars focus exclusively on wars involving nonstate actors. Without undertaking any statistical analyses that would demonstrate 'new wars' to be different"11 (Lemke, 2008, p. 774). The deficit in data on non-state actors would need to be remedied should scholars investigate power-politics theories (Lemke, 2008, p. 774). To bypass this setback, Lemke goes outside the COW data set to examine the Rio de la Plata region from 1810-1862 to test his general question: Do non-state actors behave like states? Lemke restricts his analysis to what he terms "Autonomous Political Entities" (APEs) because they possess territory and preference.

First, to be designated APE an actor necessarily, "Controls territory by asserting claims to it, and then either by having those claims respected by competitors or by defending the claim when competitors challenge it" (Lemke, 2008, p. 776). An APE achieves independent control, to paraphrase Lemke, through a formal recognition by other actors of an APE's territory (for example a peace treaty), by the successful military defense of the territory, or by an APE's declaration of independence going unchallenged (Lemke, 2008, p. 777). Some scholars question the authenticity of the region's "anarchic environment", but, "Within that subsystem, the actors formed alliances, signed treaties, and fought wars against each other" (Lemke, 2008, p. 777). In fact, Lemke documents 10 wars $^{12}$ that occurred between 1819 and 1861 among the APEs. Numerous historians speak to the anarchic nature of the region including Cristensi who "writes that each

\footnotetext{
${ }^{11}$ Lemke also alleges that "'new wars' may not be new at all. Nonstate actors have played extensive roles in wars at other times in history" (Lemke, 2008, p. 775).

12 "I [Lemke] classify their violence as wars whenever the historical record indicates at least 1,000 soldiers lost their lives in combat" (Lemke, 2008, p. 777).
} 
'adopted a flag and emblem as symbols of its own cultural unity... and if the process had continued uninterrupted, the provinces would have grown into nations' $(1961,386)$. He adds: 'Functionally, the provinces viewed themselves as independent states...' (400)" (Lemke, 2008, p. 777).

Second, Lemke's dataset contains 5,000 annual dyadic observations. The historic records indicate if APEs were satisfied with the status quo established by Buenos Aires (Lemke, 2008, p. 779). Lemke codes each dyad as being in agreement or disagreement about the status quo based on whether the actors shared preferences about Buenos Aires' role in the region and specifically about Buenos Aires' control of trade. As the dominant APE, Buenos Aires was chosen because of its controlled access to the international economy via the port. And, PTT is most appropriately analyzed against dyads including the dominant state because states fight to control the terms of the status quo (Lemke, 2008, p. 780).

To summarize the results, Lemke's analysis closely aligns with the tenets of PTT. It shows that the variables, parity, and status quo dissatisfaction, are correlated with the onset of war. Additionally, when the parity and dissatisfaction interact, they greatly increase the probability of war which is consistent with $\mathrm{PTT}^{13}$ (Lemke, 2008, p. 780). Brambo, Clark and Golder (2006) calculate the interactive marginal effects of parity and status quo dissatisfaction. They find that the probability of war, for dyads including

\footnotetext{
${ }^{13}$ The study also demonstrates that "the interactive effect of Parity and Status Quo Dissatisfaction is positive and statistically significant, and the positive multiplicative term is larger than the absolute value of the sum of the two constituent elements" (Lemke, 2008, p. 780). Meaning
} 
Buenos Aires, is 11 percent higher when status quo dissatisfaction is present but parity is at its minimum observed valued. When status quo dissatisfaction is present and parity rises to its maximum observed value, the probability of war onset rises to 57 percent (Lemke, 2008, p. 781). Lemke believes that this analysis, "Suggests that power transition theory may be as useful for anticipating wars among APEs as it has been shown to be in accounting for international wars among official states" (Lemke, 2008, p. 781). Like the APEs in the Rio de la Plata, non-state actors in Syria display similar qualities. They maintain territories, sign agreements, and sometimes go unchallenged. But an important systemic difference exists, specifically in Syria, non-state actors have engaged in hostilities and cooperation with state actors. To my knowledge, no studies use PTT to examine state actors engaged in regional sub-state systems.

It is worthwhile to examine the intrastate Syrian Civil War for three reasons. First, Syria represents a microcosm of the global anarchic environment. Second, Syria's proximity to the three regional hierarchs, Russia, Iran, and Turkey, make it a likely zone for cooperation or conflict because "Proximity increases interactions between countries, forces countries to take each other seriously, and increases the potential for disputes"14 (Tammen, et al., 2000, p. 66). Third, the Syrian Civil War encapsulates both state and non-state actors whose interactions may add to the PTT. If the Syrian non-state actors maintain the same characteristics as APEs they can be analyzed through the prism of

\footnotetext{
14 "Realists, including Stephen Walt and Stephen Krasner, identify the importance of geography, which affects both the utility of employing military force and access to raw materials" (Brooks, 1997, p. 456).
} 
PTT. Kim's alliance concept could possibly be transferred to the subnational level where foreign powers support one side over another in reestablishing order in a failed state. 


\section{Chapter 3: Global Environment the Status Quo vs Challenger}

After WWII the United States emerged as the world's hyper-power, but did not achieve global hegemony. As a dominant power, the United States manages a status quo of nations with like ambitions that fulfill roles within a hierarchy (Tammen R. L., 2006, p. 564). Near the end of the Cold War, Doyle argued that Kant's liberal internationalism "best accounts for what we are", meaning liberal internationalism has shaped the norms and rules that govern the US status quo (Doyle, 1986, p. 1151) ${ }^{15}$. To be precise, Ikenberry defines liberal internationalism as a belief that "Democracies arein contrast to autocratic or authoritarian states-particularly able and willing to operate within an open, rule-based international system and to cooperate for mutual gain" (Ikenberry, 2009, p. 72). According to Tammen, the US builds and maintains a political and economic system that promotes, but, "Does not absolutely insist upon, democracy, human rights, a free press, and open economic practices" (Tammen R. L., 2006, p. 565). The US prefers political and economic liberalism to incentivize the convergence of interests, rather than using coercion to force convergence (Tammen R. L., 2006, p. 565). These commonly held commitments make for stable alliances "as exemplified by the U.S. - British relations and the larger NATO coalition" (Tammen, et al., 2000, p. 33). As Yeşilada and Tanrikulu point out, values indicate the likelihood of converging commitments and the opposite remains true of diverging values. In the liberal international status quo, western liberal-democracies are more likely to converge.

\footnotetext{
${ }^{15}$ For an in-depth look at Kant's liberal internationalism see "Liberalism and World Politics" by Michael W. Doyle.
} 
The clearest challenger to the status quo in the global hierarchy, as predicted by Organski in $1958^{16}$, is the People's Republic of China (Tammen, Kugler, \& Lemke, 2011, p. 20). Tammen, Kugler, and Lemke state that, "China and India will continue to grow in power, and one or both of them will become the dominant power in world politics later in the 21st Century" (2011, p. 10). World Bank data, using the purchasing power parity metric, shows China matching the United States in GDP in 2013 (Tammen, Kugler, \& Lemke, p. $10 \mathrm{ft}$. note 12). With China's rapid economic growth, Beijing will pursue a nuclear arsenal that will match the United States' Mutual Assured Destruction level. To Tammen, the question is not whether China will be at economic and military parity with the United States, rather the question remains, "Is China now and will it be in the future a satisfied?" (Tammen R. L., 2006, p. 571). China's rise has been marked by moves toward cooperation and conflict but Tammen states that, "Probabilities of conflict are real and rise substantially in mid-century" (Tammen R. L., 2006, p. 574).To recall Kim's alliance metric, some scholars recommend that the United States should increase its power through an "expanded alliance system" to delay overtaking (Tammen, et al., 2000, p. 173). This includes NATO enlargement and other regional organizations. But, China appears to be taking a similar approach.

In 2001, six member states (People's Republic of China, the Republic of Kazakhstan, the Kyrgyz Republic, the Russian Federation, the Republic of Tajikistan, and the Republic of Uzbekistan) came together to replace the Shanghai Five mechanism to

\footnotetext{
16 "The question is not whether China will become the most powerful nation on earth, but rather how long it will take her to achieve this status..." (Organski, 1958, p.446).
} 
form the Shanghai Cooperation Organization (SCO). Experts commonly refer to the SCO as an alliance system to counter the North Atlantic Treaty Organization (NATO) ${ }^{17}$. The SCO repeatedly denied the requests of the George W. Bush administration to send observers to the SCO meetings. "The fact that Iran was admitted as an observer in 2005 (together with Pakistan and India; Mongolia had achieved observer status in 2004) strengthened the perception that the SCO was evolving into an anti-Western alliance" (Ziegler, 2013, p. 494). The Iranian Revolution's radical ideology ${ }^{18}$ and its dissatisfaction with the status quo likely indicates the organization's overall dissatisfaction with the status quo.

According to Ziegler, the SCO has been labeled the "club of authoritarians" with a goal of "minimizing Western efforts to promote democracy" (Ziegler, 2013, p. 485). Prior to 9/11 the SCO convened the Shanghai Convention on Combating Terrorism, Separatism and Extremism with the expressed purpose of combating acts terrorism, separatism, and extremism (Albert, 2015) (Shanghai Cooperation Organization, 2001). However, "All member states must uphold the core principle of non-aggression and non-interference in internal affairs" (Albert, 2015), a principle reaffirmed by SCO members in Astana on June 9, 2017 (The Shanghai Cooperation Organization, 2017).

\footnotetext{
${ }^{17}$ To paraphrase Christopher Hitchens, Vladimir Putin views the SCO as a new Warsaw Pact with a purpose to counter NATO expansion (Hitchens, 2008, p. 7).

${ }^{18} 1$ ) In a series of speeches redacted to the book Hokumat-e Islami: Velayat-e faqih (Islamic Government: Governance of the Jurist), Ayatollah Ruhollah Khomeini asserts that "It is the duty of all of us [faithful] to overthrow tāghüt, ${ }^{18}$ i.e., the illegitimate political powers that now rule the entire Islamic world" (Khomeini, 1977, 2017). 2) The notion that God utilizes human agency to complete his will on earth (Lewis, 1990). See "The Roots of Muslim Rage" by Bernard Lewis demonstrates the differences between Western and Islamic thought on agency.
} 
Though dictatorships and monarchies are included into the US status quo, SCO's indifference to the nature of domestic rule stands in stark contrast to the current order.

In the case of Syria, the Assad regime's dictatorial rule stretches four decades and closely aligns with the nature of the SCO nations. Under Assad, the Syrian government utilized ruthless methods ${ }^{19}$ to contain sectarianism placing Damascus at odds with pluralist democracies that comprise NATO (Frontline, 2011). In a 2013 op-ed published in The New York Times, Vladimir Putin stated, "Syria is not witnessing a battle for democracy, but an armed conflict between government and opposition in a multireligious country. There are few champions of democracy in Syria" (Putin, 2013). Putin's message was clear, the democratic experiment will not work in Syria so don't try. The SCO's brutal pragmatism appeals to dissatisfied nations, like Syria, who find themselves outside the status quo-nations in the Middle East.

\section{Commencement of Syrian Civil War}

The Syrian Civil War has its origins in the popular uprisings across the Arab world known as the Arab Spring (Frontline, 2011). The uprisings arrived at the Syrian city of Daraa after teenagers who saw the uprisings online, spray painted revolutionary antiregime slogans ${ }^{20}$ on a school wall (Frontline, 2011). The teens were arrested and tortured. The Assad regime's actions prompted prodemocracy protests in Daraa that the government suppressed with live fire. Reports of the incident sparked nation-wide

\footnotetext{
${ }^{19}$ See Hama rules "In 1982, the Syrian regime launched one of the worst massacres in the history of the Middle East. The regime used artillery to level large parts of the town. Between 10,000 and 30,000 people were killed or were disappeared by the regime" (Frontline, 2011).

20 "Freedom, freedom and freedom, only" and "Down with the corrupt Assad" (Frontline, 2011).
} 
protests that began pushing for the ouster of the Assad. The Syrian Army's brutal response to the 2011 uprisings influenced the, "Defection of up to 3,000 mostly Sunni officers", though it had little impact on the Syrian Army's functionality as most were not officers of any rank (Khaddour, 2016).

The breakdown in civil order galvanized dissident groups which began taking up arms and, by 2012, opposition forces had organized in the Syrian countryside. By this time, some sources place the number of defectors from Syrian Armed forces close to 100,000 including high-ranking officers (Al-Monitor, 2012). According to Afak Ahmad, at the time the highest ranking Alawite officer to defect, "The facts on the ground in Syria favor the Free Syrian Army ... Defections are now occurring more often than at any time before, especially among high-ranking officers" (Al-Monitor, 2012). Fighting reached Aleppo and Damascus the same year with the Syrian Air Force bombarding centers of resistance (BBC News, 2016). Regional and international backers of militias and terrorist groups, organized along the lines of ethnicity and ideology, emerged to either support the Assad regime or to back change. With the guidelines established by the SCO it is no surprise that challenger nations like China and Russia came out in support of the Assad regime. The rift among status quo-nations and challenger-nations becomes more apparent in the United Nations Security Council. Of the five permanent members on the Security Council, the United States, Great Britain and France are NATO signatories. The other two, China and Russia, are SCO members. Of the eight resolutions that could result in a violation of Syria's sovereignty, Russia has vetoed eight while China has 
vetoed six resolutions and abstained twice ${ }^{21}$ (McKirdy, 2017) (United Nations, 2017).

China's ${ }^{22}$ lengthy relationship with the Assad regime in Syria may signal Chinese interest

in the Syrian conflict but Russian proximity and economic interests in Syria made Russia

the likely participant. The UN's inability to pass any resolutions that could result in

coercive action led Qatar and Saudi Arabia to take a more aggressive stance calling for

military intervention (Lund, How Assad's Enemies Gave Up on the Syrian Opposition,

2017).

At the commencement of the civil war, the US-Turkey-Gulf State alliance began

efforts to remove the Syrian Baathist regime and replace it with a moderate Sunni

government. Lund cites former Secretary of State Hillary Clinton's senior adviser on

Syrian affairs Frederic $\mathrm{C}$. Hof as being instrumental in the organizing of the Friends of

Syria. In February 2012, after Russia utilized its UN Security Council seat to veto

measures against Assad, the Friends of Syria was established to confront the regime.

The Friends of Syria coalition was comprised of 114 nations that agreed that the Assad

Regime, "Lost legitimacy and should stand aside to allow the launching of a sustainable

\footnotetext{
${ }^{21}$ The vetoed resolutions condemning the Assad regime's use of chemical weapons or humanitarian violations can be seen as part of a larger strategy to preserve the Assad regime in Syria (United Nations, 2017).

${ }^{22}$ China's diplomatic relations began with Syria in the 1950s. Visiting Damascus in August of 2016, Guan Youfei, head of Office for International Military Cooperation, "reached consensus on improving personnel training, and the Chinese military offering humanitarian aid to Syria" (The Telegraph, 2016). Since then, China has provided \$16 million in humanitarian aid (The State Council of the People’s Republic of China, 2017) and has reportedly been involved in covert operations. China has cited concerns with the growing Chinese Uyghur militants fighting alongside rebels in Syria. The numbers range from a few hundred to thousands from depending on the source. China has been clear about their intent of battling the Turkistan Islamic Party but it is unknown if this means a wider military campaign (Webb, 2016).
} 
political transition process in conformity with the Geneva communiqué" (Lund, How Assad's Enemies Gave Up on the Syrian Opposition, 2017).

Around the same time, the US famously trafficked Muammar Gaddafi's weapons to Free Syrian Army (FSA) fighters, notably, "20,000 portable heat-seeking missiles-the bulk of them SA-7s-that the Libyan leader obtained from the former Eastern bloc" (Kelley, 2012). The weapons were transferred to Turkey where they crossed the Syrian border. Qatar, who also supplied opposition fighters in Libya, also began supplying arms covertly to Syrian rebels ${ }^{23}$ beginning with Chinese FN-6 air defense missiles (Mazzetti, Chivers, \& Schmitt, 2013). Other states contributed at least $€ 1.2$ billion in weapons (Saudi Arabia €829 million; Jordan €155 million; UAE €135 million; Turkey €87) from the former Eastern Bloc countries, primarily Croatia. "Out of the 1.2 billion euros in weapons and ammunition approved for export, about 500 million euros have been delivered, according to UN trade information and national arms export reports" (Marzouk, Angelovski, \& Patrucic, 2016). Turkey maintained the Sunni opposition to Assad by providing safe havens for fighters, CIA training operations, and allowing weapons to be trafficked through its southern border (Apuzzo \& Mazzetti, 2016).

\footnotetext{
${ }^{23}$ Representing FSA, the Coalition for Syrian Revolutionary and Opposition Forces opened their headquarters in Doha with the mission of "transition towards a free and democratic country" (National Coalition of Syrian Revolution and Opposition Forces, 2017). An Embassy for the Syrian Arab Republic (Opposition to Assad) in Doha opened in 2013. Qatar's diplomatic efforts have led to vast amounts of capital headed to regions controlled by rebel forces, by some accounts close to $\$ 3$ billion in 2013. "Qatar has a lot of money and buys everything with money, and it can put its fingerprints on it,' says a rebel officer from the northern province of Idlib interviewed by the FT" (Fielding-Smith \& Khalaf, 2013).
} 
The Obama administration initially provided \$25 million for "non-lethal" assistance to the Syrian opposition (Hosenball, 2012) and further authorized another $\$ 500$ million for a failed program to train rebels (Rizzo, 2015). “Arms program Timber Sycamore quickly grew into one of the most expensive covert programs in CIA history, spending about a billion dollars per year by $2015^{\prime 24}$ (Lund, 2017). Obama amended Timber Sycamore to arm and train rebels in Jordan and Turkey with aid of Saudi Arabia money and resources. Lawmakers criticized both programs for possibly aiding radicals and supporting an incompetent coalition of FSA fighters (Entous, 2015).

The Sunni opposition's inability to organize over a common ideology or vision for a future Syria frustrated their early success. The FSA represents but one coalition in Syria, the Assad regime and its allies remain more cohesive ${ }^{25}$. Perhaps related to the opposition's failure to organize, international backers in the status quo began to shrink from a coalition of 114 nations to the London 11 by 2013 (United States, the United Kingdom, France, Germany, Italy, Qatar, Saudi Arabia, Turkey, the United Arab Emirates, Jordan, and, Egypt) (Lund, How Assad's Enemies Gave Up on the Syrian Opposition, 2017).

\footnotetext{
${ }^{24}$ Based on information gathered from an article in The Washington Post documenting the House Intelligence Committee vote to cute 20 percent of classified funds going to, presumably, Timber Sycamore (Miller \& DeYoung, 2015).

${ }^{25}$ The Syrian Army appears clumsy and unprofessional, they have set aside sectarian differences in favor of pragmatic operations. Khaddour observes that the, "Army's networks of patronage and nepotism ${ }^{25}$, which predate the war, have morphed into a parallel chain of command that strengthens the regime" (Khaddour, 2016).
} 


\section{Chapter 4: Dyads Prior to the Fall of Aleppo}

\section{Russia to Syria}

Russian-Syrian relations began as French forces withdrew 1946 with financial and technical support. The Russian military presence in Syria began in the 1970s with the construction of a Russian naval facility in Tartus (Khaddour, 2016). In the 1960s and '70s nearly 16,000 Soviet military personal were sent to Syria as instructors (Vicente Caro, 2017). The USSR denounced Israel during the Six Days War that began on June 5, 1967 and broke diplomatic ties with Israel on the June $10^{\text {th }}$ (Vicente Caro, 2017). After Hafez al-Assad came to power relations were sustained bases on ideology and 40 thousand Syrian citizens received degrees from Soviet educational institutions (Vicente Caro, 2017). From 2007-2010 Syria arms deals more than doubled the previous three years from $\$ 2.1$ billion to $\$ 4.7$ billion (Herszenhorn, 2012). In 2005, to paraphrase Kheder Khaddour, Russia forgave $\$ 10$ billion in debt on a $\$ 13$ billion loan to modernize the Syrian military.

After the Civil War began, Syria quadrupled its military expenditures for four years with just under half going towards Russian made equipment. Figure 3 shows that Russian military exports to Syria increased by 24.4 percent from 2011 to 2012 at the commencement of the Syrian Civil War. To contextualize Moscow's generous military aid, "In January 2012 alone, the regime received 60 tons of ammunition from Moscow" (Khaddour, 2016). Russia's commitment to the Assad regime wasn't just limited to 


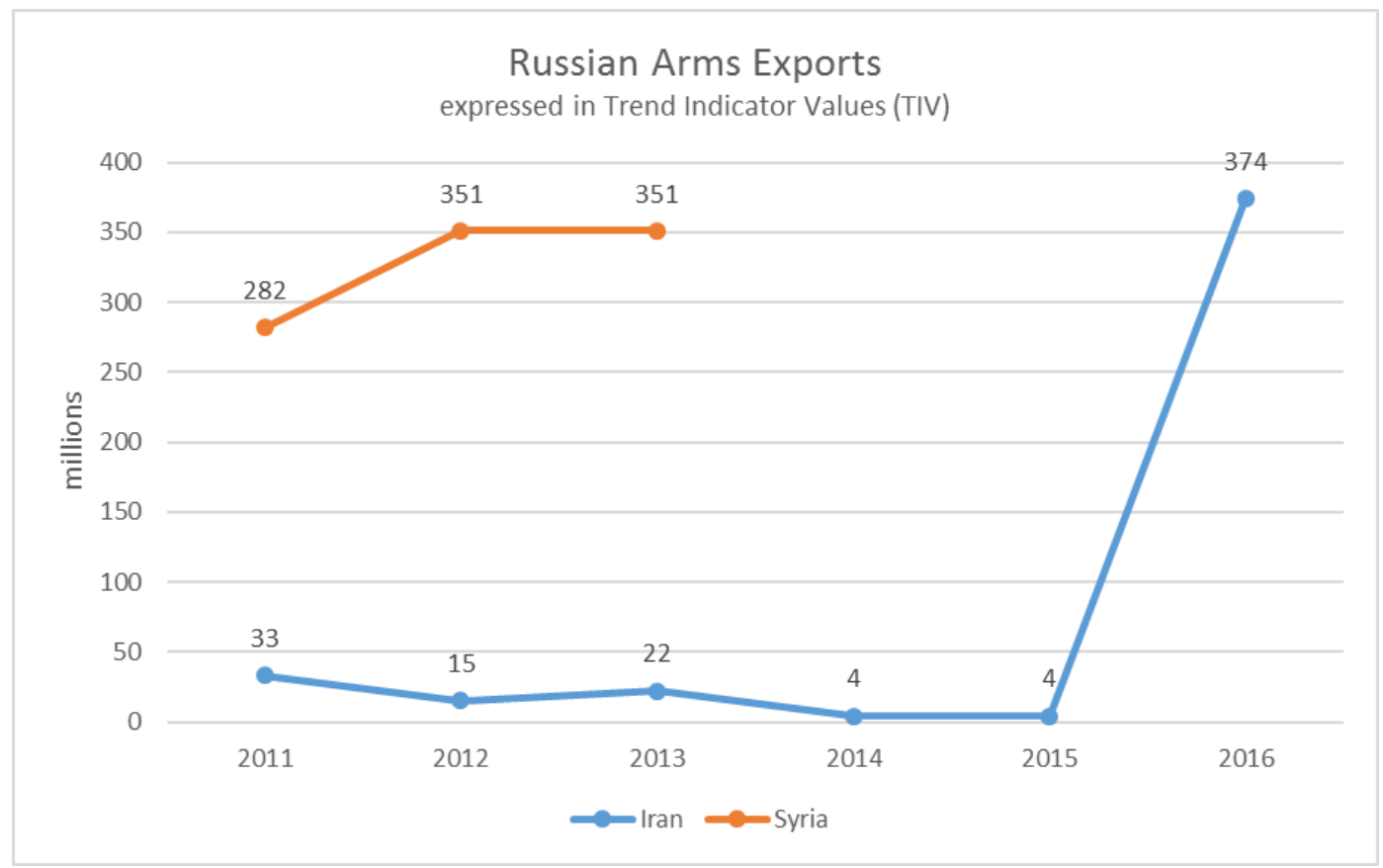

Figure 3 Data Gathered from (SPIRI, 2017)

military exports. A contract drafted in August of 2015 between the Russia government and the Assad regime outlined the conditions for the Russian aviation group's indefinite deployment in Khmeimim airbase in the Syria's Latakia province (Birnbaum, 2016). In September 2015, the Kremlin bombed rebel-held areas in the Homs province formally entering into the current Syrian Civil War (McDonnell, Hennigan, \& Bulos, 2015). To aid the air campaign, the Russians created the Fourth Corps a unit staffed by Syrian, Russian, and Iranian officers to coordinate with ground forces comprised of the Syrian Army and militia forces loyal to the Baathist regime (Khaddour, 2016). After the recapture of Latakia, Homs, and Hama along the western corridor of the country, the Russian air campaign shifted north to Aleppo and east toward the Euphrates River.

\section{Russia to Iran}

Officially, Iran has one formal ally, the Syrian Arab Republic (Abedin, 2017). Whether or not Russia amounts to a formal ally is a legal question. Article 152 in the 
Constitution of the Islamic Republic of Iran rejects all forms of foreign domination and preservation of the, "Non-alignment in relation to the domineering powers" (Islamic Republic of Iran Constitution). These amendments have a historical perspective especially concerning Russia. Iran's defeat in the Russian-Persian Wars of the 18th and 19th centuries concluded with the treaties of Golestan (1813) and Turkmenchay (1828), which brought the Persian Caucuses under Tsarist Russia (Tarock, 1997, p. 215). According to Abedin, "The loss of the Caucasus - and the pain associated with it - has left a lasting impression on the modern Iranian psyche. From an Iranian perspective, that dispossession remains the perennial backdrop to Russian-Iranian relations" (Abedin, 2017).

Twentieth century history has been no less turbulent. Iran and the USSR signed the 1921 Friendship Treaty to remark their borders to the Caspian Sea region. The treaty also kept the prohibition of Iranian naval forces, left over from Golestan treaty, in the Caspian Sea (Tarock, 1997, p. 215). During the Cold War, Iran under Pahlavi was a satisfied actor within the status quo. After the 1979 Islamic Revolution, the two ostracized nations made a "strategic alliance", based on Russia's need for foreign currency, a friendly Muslim state in Central Asia, and Iran's need for Russian arms, new technologies (Tarock, 1997, p. 207). But, the spread of communism in Iran, in the Caucuses, and the Soviet Union's support for Saddam Hussein during the Iran-Iraq war continued to strain relations (Joobani \& Mousavipour, 2015, p. 142).

The Syria conflict initiated stronger ties and cooperation between Tehran and Moscow. As can be seen in figure 3, after Russia commits to supporting Assad in 2015, 
military exports to Iran increase by more than 9,000 percent. The Joint Comprehensive Plan of Action (JCPOA) agreement between the p5+1 and Iran on July 14, 2015 partially lifted sanctions on Iran (Kozhanov, 2016, p. 2). As one of the negotiators, Russia hopes the agreement will end Iran's pariah status that has caused Russian-Iranian trade to fall by 30 percent annually between 2011 and 2014 (Kozhanov, 2016, p. 2). The agreement will permit Tehran to make payments on parts and services to Iran's nuclear program, Russia to export weapons to Iran, and for Gazprom and Lukoil to reengage in commerce with the Islamic republic (Kozhanov, 2016, pp. 2-3). In July of 2015, Major General Qassem Suleimani, the Quds Force's leader, arrived in Moscow reportedly asking for Russian intervention and, "Describing what the Russians could most usefully do" (Kagan \& Bucala, 2016, p. 13). Russia's bombing campaign that was closely coordinated with Iranian proxies ensued. The New York Times drew attention to Moscow's friendly relationship with Iran, noting that Russia is the first foreign power to operate on Iranian soil since WWII. The base's strategic location, in the Hamadan province in northwest Iran, will make Russian bombing routes to Syrian targets 1,000 miles shorter (Sanger \& MacFarquhar, 2016).

\section{Iran to Syria}

Iranian support of the Syrian regime began with Hafez al-Assad in the 1980s and continued after his death to his son Bashar. Syria was one of the first nations to recognize the Islamic Republic of Iran. As dissatisfied nations outside the status quo their interests often coincided. Iran repeatedly deemed the Assad regime necessary for Iranian security using Syrian territory to supply its proxies, Islamic Jihad and Hezbollah 
(Kagan \& Bucala, 2016, p. 11). The Assad regime had previously courted Turkish officials in a grand rapprochement isolating the Islamic Republic, but after the US invasion of Iraq, Damascus sought to bolster ties with Tehran. Iranian authorities began to grow close to the Shia majority taking power in Baghdad. In the winter of 2005 Muhammad Naji al-Otari traveled to Iran and concluded a mutual defense pact (Lawson, 2007, p. 41). Later that year, Assad became the first foreign leader to visit the newly-elected Mahmud Ahmadinejad. In October, the head of Syrian military intelligence visited with the IRGC commanders and encouraged Hezbollah to find ways to achieve material support from Iran via Syria (Lawson, 2007, pp. 41-42) (Slackman, 2006). The relationship further improved when Iranian President Ahmadinejad visited Syria in January of 2006 and Assad affirmed his support for Iranian nuclear ambitions. During Ahmadinejad's visit, Lawson reports that both heads of state confirmed to Secretary General Hassan Nasrallah their support for Hezbollah (Lawson, 2007, p. 42). In the summer of that year, tensions escalated when Hamas kidnapped an Israeli soldier and Israel Defense Force (IDF) responded by conducting operations in the Palestinian territories (Lawson, 2007, p. 45). After the soldier went missing, an Israeli Justice Minister mentioned that the IDF may carry out actions against Hamas targets in Syria. In response, Hezbollah kidnapped two more soldiers and Ahmadinejad warned that an Israeli attack on Syria would be met with "crushing response" from Tehran (Lawson, 2007, p. 45). The Israeli Air Force began bombing Hezbollah's rocket inventory and the IDF crossed the border into southern Lebanon to clear out terrorist camps. Operations were contained to Lebanon in 2006, 
however, Israeli jets bombed a secret nuclear reactor in Al Kibar, Syria in 2007 (Broad \&

Mazzetti, 2007). Needless to say, Israeli actions were not met with crushing force.

The depth of the Islamic Republic's devotion to Assad was demonstrated by their continued financial support of Syria in 2013, despite Iran being under American sanctions. Filkins states that, "They [Iranians] were unstinting in their efforts to save Assad. Among other things, they extended a seven-billion-dollar loan to shore up the Syrian economy" (Filkins, 2013). After central authority crumbled in Syria in 2011, local and Iranian-sponsored Shia militias began to supply the regime's infantry needs (Khaddour, 2016). Iran's proxy network is as old as the revolution itself. Reporting for The New Yorker Dexter Filkins relates,

The first big opportunity came in Lebanon, where Revolutionary Guard officers were dispatched in 1982 to help organize Shiite militias in the many-sided Lebanese civil war. Those efforts resulted in the creation of Hezbollah, which developed under Iranian guidance. Hezbollah's military commander, the brilliant and murderous Imad Mughniyeh, helped form what became known as the Special Security Apparatus, a wing of Hezbollah that works closely with the Quds Force. With assistance from Iran, Hezbollah helped orchestrate attacks on the American Embassy and on French and American military barracks (Filkins, 2013).

Proxies have enabled the Iranians to extend their operational theater covertly, in turn providing Iran with plausible deniability ${ }^{26}$. Prior to the Syrian Civil War, Iran financed Hezbollah with $\$ 100$ million to $\$ 200$ million annually. Levitt states, "Syria has actually integrated elements of Hezbollah's military units into the Syrian army in Lebanon" (Hezbollah Finances:Funding the Party of God, 2005). These preexisting relationships

\footnotetext{
${ }^{26}$ Testifying before before the Senate Committee on Foreign Relations, J. Matthew Mcinnis said that proxies "give the IRGC [Islamic Revolutionary Guard Corps] a degree of plausible deniability" (McInnis, 2016). Kagan emphasizes proxies also give "Iran a high degree of plausible deniability regarding the operations of those proxies" (Kagan \& Bucala, 2016, p. 10).
} 
established a network of confidants across the region prior to the civil war. In fact, "In 2012, the IRGC-QF [Iranian Revolutionary Guard Corp- Qods Force] established with Syrian volunteers the National Defense Forces (NDF) militia, modeled on the IRGC's Basij force, to assist Syria's regular army" (The Soufan Group, 2015). According to Kagan and Bucala, support has come from the Qods Force in the form of capital funds, military equipment, and advisory roles (Kagan \& Bucala, 2016, p. 11). Shoring up support for the Assad regime in 2013, Hassan Nasrallah, promised victory as dozens of Hezbollah fighters were reportedly killed in taking the border town of Qusair (BBC News, 2013).

By mid-2014 ISIS had seized Mosul, Iraq prompting Iraqi Shia militias to return home to fight. Lebanese Hezbollah purportedly sent some 1,000 fighters to Syria while Iran stepped up efforts to recruit Shia Afghan and Pakistani volunteers (Kagan \& Bucala, 2016, pp. 13-14). The Assad regime's tenuous position in 2015 deepened Iran's commitment. According to statements made before the Senate Committee on Foreign Relations, Iranian proxies sent to Syria included:

- Lebanese Hezbollah: 45,000 fighters, of which 21,000 are full time, and 6,000 to 8,000 are currently deployed to Syria

- Badr Corps Brigades: between 10,000 and 20,000 fighters

- Kata'ib Hezbollah: likely a core group of around 1,000 fighters, with 10,000 or more mobilized through its main subsidiary Saraya al-Difaa al-Shaabi and 1,000 to 3,000 likely deployed to Syria

- Asa'ib Ahl al-Haq: approximately 10,000 fighters, and 1,000 to 3,000 likely deployed to Syria 
- Afghan Fatemiyoun Brigade: 2,000 to 3,000 thousand fighters deployed to Syria, but total numbers for the group are unknown

- Pakistani Zainabiyoun Brigade: up to 1,000 fighters deployed to Syria, but total numbers for the group are unknown

- Syrian National Defense Force: approximately 100,000 mobilized Syrian fighters

(Mcinnis, 2016, p. 4)

The battle to reclaim Aleppo ${ }^{27}$ began in $2012^{28}$ between FSA and Sunni

extremists, and the Syrian government allied with Iranian militias. The city, known as a bastion for government loyalists, faced numerous car and suicide bombings, shaking the government's hold and costing 6,000 lives in the process (MacFarquhar, 2012). Unable to shake the opposition, Kagan believes the battle for Aleppo forced IRGC members from a train, advise, and assist (TAA) mission to active combat roles (Kagan \& Bucala, 2016, p. 5). Kagan estimates, "187 causalities among Iranian nationals in Syria between October 1, 2015 and February 26, 2016" (Kagan \& Bucala, 2016, p. 6).

\section{Turkey to Syria}

Within the last 30 years, Syrian-Turkish relations have gone through ebbs and flows of belligerence and reconciliation. To paraphrase Lawson, in the late 1980s the Turkish government expressed anger at the Assad regime's permissive attitude to Kurdish and Armenian militants that besieged Turkish targets from Syrian territory. "In October 1989, a pair of Syrian MiG-21 interceptors crossed into Turkish airspace east of

\footnotetext{
${ }^{27}$ The importance of Aleppo commercially, culturally, and its centrality to Syrian identity should be noted. See: "Animosity toward Iran reaches fever pitch in Turkey after Aleppo" by Semih Idiz.

${ }^{28}$ For a detailed battle timeline see: http://www.thealeppoproject.com/conflict-timeline/
} 
Iskandarun and shot down a Turkish survey plane, killing the five civilians on board" (Lawson, Syria's Relations with Iran: Managing the Dilemmas of Alliance, 2007, p. 30). Ankara retaliated by shutting the southward flow of the Euphrates River for a month. Turkey's use of water as a political tool would occur again in the drought of 2008 (Fisunoğlu, 2016, p. 20). Throughout the 1990s the Turkish government pressed its Syrian counterparts on its support of the PKK and PKK founder Abdullah Öcalan's sanctuary in Syrian territory (Fisunoğlu, 2016, p. 20). After Hafez al-Assad died, SyrianTurkish relations improved. Security and economic issues were tackled in a broader effort named the "Memorandum on Understanding" (Lawson, 2007, p. 35). Fisunoğlu informs us that President Erdoğan, "Visited Syria 11 times while he was the prime minister" (Fisunoğlu, 2016, p. 23). By comparison, Erdoğan visited Germany, which hosts some 3 million citizens of Turkish descent ${ }^{29}, 15$ times. The opportunity for regime change during the Syria Civil War rebuffed the Syrian-Turkish rapprochement.

Turkey has actively engaged in regime change by supplying arms and fighters to opposition groups. "Weapons had begun trickling into Syria as early as 2011, through backdoor channels organized by Islamist networks, smugglers, merchants, and Bedouin clans, but also with increasingly overt support from Turkey, Qatar, and Saudi Arabia" (Lund, 2017). Many of the weapons from Gulf countries and operation Timber Sycamore ended up in the hands of Free Syrian Army (FSA) fighters.

\footnotetext{
29 "As of the 2014 microcensus, nearly 3 million people with a Turkish migration background, resided in Germany" (Aydın, 2016, p. 6).
} 
From the onset, the FSA was funded mainly by Turkey and FSA founder Col. Riad al-Assad lives in Antakya in southern Turkey (Bar'el, 2016). On July 18, 2012, a successful bombing of a high level meeting with Assad's inner circle of intelligence and defense advisors in Damascus left 4 key figures dead ${ }^{30}$. Two groups claimed responsibility for the attack, Liwa al-Islam (Brigade of Islam) and the Free Syrian Army (McElroy, 2012). The attack came after several days of heavy fighting in and around the capital. The penetration of Assad's inner circle further emboldened the opposition while dealing a heavy blow to the regime (Levs, 2012). The FSA's initial successes in Syria and competent leadership garnered international support and further strained TurkishSyrian relations. However, David L. Phillips documents ISIS-Turkish links which includes agents from the National Intelligence Organization (MIT) illegally smuggling weapons to ISIS to openly permitting ISIS recruits world-wide passage to Syria (Phillips, 2014). Ankara's to support for radical Islamists raise suspicions among Turkey's Western allies who wonder if they are pursuing similar objectives.

Turkish action in Syria has not just been initiated through proxies. Ankara froze Assad regime's assets in Turkey, suspended Syrian ties with the Turkish central bank, and prohibited military sales to Damascus (Oktav, 2015, p. 6). In the summer of 2012, the Syrian regime shot down a Turkish F-4 fighter over Syrian waters (Al Arabiya, 2012).

\footnotetext{
30 The bombing took the lives of deputy defense minister Assef Shawkat (Assad's brother-in-law) and General Dawoud Rajha (McElroy, 2012). Days later national security chief Hisham Ikhtiar and former defense minister Hassan Turkmani, who attended the meeting, succumbed to their injuries sustained in the blast (CBS/AP, 2012).
} 
Syrian sovereignty was again violated in 2016 when Turkey invaded in an operation known as Euphrates Shield.

\section{Turkey to Iran}

Özcan and Özdamar argue that a structural rivalry has existed for centuries between Turkey and Iran whereby both countries compete for leadership of the Muslim world ${ }^{31}$. The rivalry represents an important backdrop to modern Turkish-Iranian relations (Özcan \& Özdamar, 2010). Beginning in the mid-‘80s Kurdish militants have conducted strikes in Turkey only to retreat to their camps in Syria and Iran. After repeated accusations that Iran was sheltering PKK guerrillas, a charge denied by Tehran, Turkish aircraft bombed suspected militant hideouts in Piranshahr in July of 1999. Similar strikes were executed three years earlier but the 1999 attacks, "Occurred a little over a week after Iran witnessed the largest anti-government demonstrations since the Islamic revolution in 1979" (Olson, 2000, p. 877). Perhaps slightly embarrassed by massive protests, the Iranian government commented on Kavakçı affair, questioning Turkish policy to ban the hijab in public service. "Kemal Kharrazi, the Iranian foreign minister, stated bluntly that 'Iran did not like Turkey's secular policies'” (Olson, 2000, p. 876). In a sharp rebuttal to comments from Tehran, Turkish generals announced on Turkish media that Osman Öcalan, the brother of Abdullah, and other PKK commanders had been given sanctuary in Iran. The reports even showed, "Several PKK guerrillas confessing that they had been trained in Iran" (Olson, 2000, p. 877). Shortly after, in

\footnotetext{
${ }^{31}$ Flanagan states "Iran's adoption of Shi'ism was originally part of an effort by the Safavid state in Persia to distinguish it from the Sunni Ottoman Empire” (Flanagan, 2013, p. 164)
} 
October of 1999, Turkish police arrested 92 members of Hizbullah ${ }^{32}$ operating on

Turkish soil, purportedly trained in Iran (Olson, 2000, p. 880). The heightened tensions in the '90s were simultaneously being by downplayed by some elements in the Turkish government.

President Erbakan, of the Naqshbandi order, initiated Turkey's shift away from the west and toward a more openly Islamic fundamentalist policy. To the dismay of western governments and secularists in Turkey, Erbakan visited Libya and Iran in 1996. The trip further aroused suspicion when Erbakan overlooked Iran's support of the PKK and closed a \$23 billion gas deal (Carkoglu, Eder, \& Kirisci, 1998, p. 208). The commercial interests established by Erbakan was part of a widening initiative to incorporate neoliberal economics in Turkey, which President Özal introduced a decade earlier. Bilateral relations improved in the 2000 s to the point where Iran became Turkey's fifth largest trading partner. "Total bilateral trade volume rose from about \$1.05 billion in 2000 to \$16 billion in 2011" (Flanagan, 2013, p. 170). Flanagan also points to the "more than 1,470 Iranian firms were operating in Turkey at the end of 2010, up from only 319 firms in 2002" (Flanagan, 2013, p. 170). The Turkish republic often acted as Iran's bridge to escape economic sanctions. The relationship proved valuable for Turkey, which imports 90 percent of its oil and gas supplies (İpek, 2017, p. 408).

\footnotetext{
32 Turkish Hizbullah is a Sunni Kurdish-led Islamist counter-PKK organization (Olson, 2000, p. 880) not to be confused with Lebanese Hizbollah.
} 
Starting in the early 1980s Turkey exported goods to Iran in exchange for oil and gas, a practice that carried over to AKP years (Özcan \& Özdamar, 2010). In 2002 the two countries completed a pipeline extending from the gas fields in Tabriz to Ankara (Flanagan, 2013, p. 170). Iran is the second largest energy supplier to Turkey after Russia, supplying 18 percent of Ankara's total gas imports and 31 percent of its total oil imports in 2014 (Ijpek, 2017, pp. 407-408). By 2011, Iranian oil accounted for 51 percent of Turkish oil imports. Flanagan claims that Iranian sanctions ${ }^{33}$ account for concessions on oil prices undoubtedly benefiting Turkish consumers (Flanagan, 2013, p. 171). The extra capital also feeds Tehran's ailing economy.

Prior to 2011, Turkey voiced concern of Iran's support for radical Shia groups in the region (Flanagan, 2013, p. 171). After the Arab Spring "Turkish officials remain[ed] greatly alarmed by Iran's fanning of Shia-/Sunni tensions in Bahrain, Syria, Lebanon, and Iraq, and support for radical Shia groups in Azerbaijan, which they characterize as an ideological struggle for influence" (Flanagan, 2013, p. 171). Oktav claims that when the Syrian crisis began Tehran wanted to continue amicable ties with Ankara as Turkey signed military agreement with Qatar and American had expanded its military presence in the Persian Gulf (Oktav, 2015, p. 12). Turkey and Iran took opposing sides in the Syrian Civil War supporting proxies that fought one another. However, Oktav cites gas

\footnotetext{
33 "Turkey came under considerable pressure from the United States and the European Union to reduce imports of Iranian oil or risk financial sanctions directed at Tehran over its nuclear program" (Flanagan, 2013, p. 171).
} 
deals and counter terrorism measures cooperative measures throughout the period (Oktav, 2015, pp. 14-16).

\section{Kurds-Turkey-US-Russia}

The International Crisis Group estimates that the conflict, between the MarxistLeninist PKK (The Kurdistan Workers' Party/ Partiya Karkerên Kurdistanê) and the Turkish republic, has cost the lives of 30,000-40,000 people since 1984 (Mandıracl, 2016). In 1999 Turkish authorities arrested the founder of the PKK Abdullah Öcalan's in Kenya. Many PKK fighters subsequently escaped to the mountainous terrain of northern Iraq and Syria from their bases in eastern Turkey. According to Gurses, "The neighboring Kurdish territories allowed the PKK to survive and regroup" (Gurses, 2015, p. 144). It was in Syria that the PKK went on to form the Democratic Union Party (PYD) and Party of Free Life of Kurdistan (PJAK) in Iran, and resurface in Turkey as a credible threat in the mid-2000s (Gurses, 2015, p. 144). In a 2013 interview, Abdullah Öcalan's brother Osman admits to founding the PYD stating:

I founded the PYD, as I did PJAK (the PKK's Iranian arm). We did not use the word 'Kurdistan' in the party's title since we did not want to provoke the Syrian regime. The PYD is connected to the PKK, and acts upon on PKK orders. We founded the PYD in Qandil. We held the first general PYD congress in October 2003. We trained the cadres in Qandil (Yahya, 2016).

A Baathist crackdown on an uprising in Qamishli (Syrian Jazira Canton) left more than 30 Kurds dead in 2004 giving the previously disconnected Syrian Kurdish regions of Afrin, Kobani, and Jazira a sense of "linked fate" (Khaddour \& Mazur, The Struggle for Syria's Regions, 2013, p. 6). The PYD took up residence in the cantons filling the security void. From the Syrian war's commencement, "The PYD has taken charge of the 
campaign to defend the Kurds of the north-eastern provinces" (Lawson, 2014, p. 1352). Lawson argues that the PYD militia, the Popular Protection Units (YPG), proved to be a competent organization. The PYD, "fought the Assistance Front and ISIL to a stalemate on two main fronts: the oil-producing areas around al-Hasakah and Dair al-Zur [Deir alZour], and the towns that lie along the border with Turkey" (Lawson, 2014, p. 1352). By the summer of 2012 the Baathist regime was mired by conflict. Perhaps because of Kurdish competence the, "Regime unilaterally withdrew most of its soldiers and bureaucrats from the Afrin and Kobani regions and part of Jazira, effectively leaving local leaders and the PKK's affiliate, the PYD, to administer these areas without a fight" (Khaddour \& Mazur, 2013, p. 7). In Kurdish regions confronting Jabhat al-Nusra and ISIS, the regime allowed near full autonomy (Khaddour \& Mazur, 2013, p. 7).

Turkish policy toward Syria pivoted from regime change toward counterterrorism when the YPG captured Tal Abyad from ISIS in June of 2015. The city lies on the border with Turkey and is a strategic enclave connecting the Kurdish cantons in northern Syria (Heller, 2017). ISIS retaliated by bombing a Federation of Socialist Youth Association rally in the majority-Kurdish town of Suruç, Turkey. The youth rally was held to support reconstruction efforts for the Syrian Kurdish city of Kobani, previously held by ISIS (Letsch, 2015). Heller reports that the Kurds took ISIS'S occupation of Kobani as proof that Erdoğan's government cooperated with ISIS. It was later found that the Suruç bomber was a Turkish member of ISIS further inflaming tensions (Yeğinsu, 2015). These allegations are nothing new. Kurds have long suspected 
Erdoğan of collaborating with extremists especially along the Turkish Border ${ }^{34}$. For instance, even with U.S. assistance, "Over spring and summer 2015, the northwestern cities of Idlib and Jisr al-Shughour were taken by an Islamist force spearheaded by alQaeda fighters" (Lund, 2017). The circumstances precipitated a breakdown of two-anda-half year ceasefire that has since led to 3,200 deaths between PKK and Turkish security Forces ${ }^{35}$ (International Crisis Group, 2017).

\section{Russia to Turkey}

Turkish-Russian relations have historically been tumultuous. The Ottoman Empire and Tsarist Russia went to war seven times in the course of two and one-half centuries (Sadak, 1949, p. 450). The Kemalist republic and the Soviets had more in common ideologically and signed their first treaty in 1921, prior to the republic's declaration of independence in 1923. The agreement established the border between the USSR and Turkey. At first, the relationship was harmonious but soured after the 1936 Montreux Convention giving Turkey control over the Bosporus and the Dardanelles (Sadak, 1949). The USSR accepted Turkish neutrality during WWII because a clause in the Montreux Convention, "Gave Turkey the role of faithful guardian of Soviet security in the Black Sea" (Sadak, 1949, p. 458). However, the topic of the Dardanelles persisted post-war straining Russian-Turkish relations. Turkey's weak economy and war-ravaged people, reported the American Ambassador, would not "be able to maintain indefinitely a defensive posture against the Soviet Union" (Satterthwaite, 1972, p. 77). To

\footnotetext{
${ }^{34}$ YPG leaders accused Turkey backed ISIS militants that stormed Tal Ma'ruf ${ }^{34}$ and destroyed a memorial to an assassinated Kurdish opposition figure (Lawson, 2014, p. 1355).

35 The numbers were last updated October 14, 2017.
} 
summarize Satterthwaite, the Truman Doctrine passed in 1947 and the Marshall Plan (Economic Recovery Act) ratified on April 3, 1948, approved more funding for Greece and Turkey. Unfortunately the Soviet threat persisted. Turkey furthered its commitment to the postwar liberal democracies by contributing 5,000 soldiers to UN forces in Korea. In 1951, Turkey was invited to join NATO and was formerly accepted in 1952 (Satterthwaite, 1972, p. 81). Turkey's alignment with the west placed them at odds with the USSR and they would remain Cold War adversaries until the '90s. Turkish-Russian relations, Gürel \& Tzimitras contend,

Started improving following the dissolution of the Soviet Union in 1991 but have gained real momentum since the mid-2000s when trade, particularly in energy (mostly Turkish imports of Russian natural gas), boomed alongside increasing Turkish investments, especially in the construction industry. While the volume of trade between Russia and Turkey increased from $\$ 3.4$ billion to only $\$ 4.5$ billion during 1996-2000, the change during 2001-2008 was from $\$ 4.3$ billion to $\$ 38$ billion (Gürel \& Tzimitras, 2015, p. 28).

Flanagan cites a total bilateral trade topping $\$ 30$ billion in 2011, making Russia Turkey's largest trading partner after the EU bloc since 2008 (Flanagan, 2013, p. 167). İpek claims that Turkish energy consumption occurred at a faster growth rate than any country within the Organization for Economic Co-operation and Development (OECD) in the last 10 years (Ipek, 2017, p. 407). Turkey imports 75 percent of its energy relying primarily on fossil fuels, and, "In 2014, Turkey imported 73 percent of its gas supplies from only two countries (Russia and Iran)" (Ipek, 2017, p. 408). Since the Syrian Civil War began, Russia maintained its monopoly in the Turkish gas markets thanks to exports via 
the Blue Stream pipeline ${ }^{36}$. But, Turkish dependency on fossil fuels is not a one-way street. In 2014, the EIA reported that, “Oil-and-gas exports make up 70\% of Russia's $\$ 515$ billion annual exports, and 52\% of the federal budget" (The Economist, 2014). If the current trends remain, monopolizing the energy demand is a matter of national security for the Kremlin.

Turkey and Syria represent vital transshipment points for Middle East energy producers to European markets. The European Union (EU) is the largest importer of energy in the world. The two largest suppliers of natural gas to the European Union are Norway and Russia, together they account for roughly 70 percent of gas imports ${ }^{37}$ (European Commission, n.d.). While the United States consumes most of its supply domestically, the world's largest exporters of natural gas are Russia (205 billion cubic meters (bcm)), Qatar (117 bcm) and Norway (115 bcm) (IEA, 2017, p. 15). Before the conflict in Syria commenced, two proposed pipeline projects would've reduced demand for Russian energy. First, an agreement between Iran, Iraq, and Syria, known as the "Islamic pipeline" was to transport gas from the Pars fields in Iran to refineries in Damascus (United Press International, 2011). From there the gas would presumably feed European markets. Second, the Nabucco pipeline was to connect existing infrastructures to transport gas from Azerbaijan to markets in Europe (Yeşilada B. , 2013, p. 101). The Nabucco pipeline would've provided the oil-rich Persian Gulf

\footnotetext{
${ }^{36}$ Though Russian exports declined by 2014, “Turkey's largest gas suppliers were still Russia (55 percent) and Iran (18 percent), and 86 percent of total imports were delivered via pipelines" (Ijpek, 2017, p. 407). ${ }^{37}$ Russia supplies 39\% of the EU's gas imports. In 2017, the United States and Russia contributed to 38.5\%, by far the largest share, of the world's total natural gas production (IEA, 2017, p. 15).
} 
countries with land access via Syria and Turkey to Europe. Currently, Turkey serves as a transit country for Baku-Tbilisi-Ceyhan pipeline ${ }^{38}$ transporting oil from central Asia and Azerbaijani fields in the Caspian Sea to Ceyhan (British Petroluem, 2017). Yeşilada comments that the pipelines crossing Anatolia have the potential to reduce Europe's dependency on Russian energy (Yeşilada B. , 2013, p. 101).

From the onset of the Syrian Civil War, Russia and Turkey have taken opposite sides. When Turkish F-16s downed a Russian Su-24 fighter on November 24, 2015 (BBC News, 2015), President Putin countered with the, "Deployment of 7,000 Russian troops to a base in Armenia across from the Turkish border and stationed in Syria advanced S400 anti-aircraft missiles and more aircraft with advanced fighting capabilities as well as more naval ships" (Yeşilada B. A., 2016, pp. 27-28). The S-400 anti-aircraft missiles deployment at the Khmeimim airbase can engage targets 248 miles away or, "At least 75 percent of Syrian territory, along with the airspaces of Lebanon, Cyprus, half of Israel and a vast part of Turkey" (RT, 2015). Turkey has continued to fund and support the Sunni opposition that regularly engaged Russian proxies.

\footnotetext{
38 "The pipeline carries oil from the Azeri-Chirag-Deepwater Gunashli (ACG) field and condensate from Shah Deniz across Azerbaijan, Georgia and Turkey. It links Sangachal terminal on the shores of the Caspian Sea to Ceyhan marine terminal on the Turkish Mediterranean coast. In addition, crude oil from Turkmenistan continues to be transported via the pipeline. Starting in October 2013, we have also resumed transportation of some volumes of Tengiz crude oil from Kazakhstan through the BTC pipeline" (British Petroluem, 2017).
} 


\section{Chapter 5: After the Fall of Aleppo the Status Quo vs Challenger}

The main anti-Assad bloc, the London 11, further declined when Russia began its air campaign in Syria. Russian airpower coupled with ground troops composed of the Syrian Army, IRGC fighters, and Shia militias recaptured Aleppo for the Syrian government in December of 2016 (Hubbard, 2016). At the time, Obama was leaving office and the incoming Trump administration's Syria policy appeared mixed. In early 2017, President Trump echoed the Obama administration's calls for Assad to leave office and for Russia to cease support of the Syrian regime (Pramuk, 2017). But in March, Secretary of State Tillerson remarked that the, "Longer-term status of President Assad will be decided by the Syrian people" (Labott, Gaouette, \& Roth, 2017). Tillerson's comments were widely received as US acceptance of the Baathist government (Harris, 2017). In April, the Syrian government used chemical weapons in violation of international law, and Washington responded by launching 59 Tomahawk cruise missiles at the Al-Shayrat Airbase ${ }^{39}$ southeast of Homs (Garamone, 2017). Despite calls from the international community to take further action, Trump voiced a desire to cooperate with Russia to counter ISIS and other extremist groups in Syria (DeYoung, 2017).

That summer, the United States, Russia, and Jordan announced a plan to create de-escalation zone centered on the border crossing of Nassib. The Nassib crossing

\footnotetext{
${ }^{39}$ According to the Atlantic the Al-Shayrat base was a strategic base that stored chemical weapons, Russian and Syrian fighters, Russian hardware, fuel, and ammunition. The Russian presence began in 2015 and persisted with the addition of new helicopters just months before the attack (Kelly, 2017).
} 
happened to be the vital economic ${ }^{40}$ land route connecting Southern Syria to Jordan and the Gulf countries (Lund, Opening Soon: The Story of a Syrian-Jordanian Border Crossing, 2017). US forces engaged and destroyed a Syrian convoy approaching the alTanf safe zone to enforce the status quo within Syria territory (Mcleary, 2017). According to Defense Secretary Mattis, a, “De-confliction line runs along the Euphrates River, with pro-Syrian and Russian forces operating to the west and U.S.-backed Syrian Democratic Forces (SDF) operating to the east" (Humud, Blanchard, \& Nikitin, 2017, p. 11). Figure 4 reaffirms Secretary Mattis' statement showing the American allied SDF forces east of the Euphrates and the Russian-Syrian alliance to the west.

In separate talks organized by Russia and Turkey, held in Astana on September $14-15$, four zones were created with the purpose of de-escalating conflict. The deescalation zones are in, "Eastern Ghouta, in certain parts in the north of Homs province, in Idlib province and certain parts of the neighboring provinces (Latakia, Hama and Aleppo provinces) and also in certain parts of southern Syria" (The Ministry of Foreign Affairs Republic of Kazakhstan, 2017). Russia, Iran, and Turkey agreed to act as guarantors of the ceasefire, sending observers to the de-escalation zones. A joint statement released by the regional hegemons announced the intent to establish a, “Joint Iranian-Russian-Turkish Coordination Center aimed at coordinating activities of de-escalation control forces in the de-escalation areas" (The Ministry of Foreign Affairs

\footnotetext{
40 "Before the fighting began, the crossing is said to have handled $\$ 1.5$ billions worth of trade per year, though by 2014 that sum had dropped to $\$ 400$ million" (Lund, Opening Soon: The Story of a SyrianJordanian Border Crossing, 2017).
} 
Republic of Kazakhstan, 2017). The guarantors of the ceasefire also reaffirm the commitment to continue the fight against Islamic extremists ${ }^{41}$ inside and outside the deescalation zone (The Ministry of Foreign Affairs Republic of Kazakhstan, 2017).

That said, the Astana Agreement, as it came to be known, does not stipulate how the observers will be deployed. Will observers form mixed units of Russian, Iranian, and Turkish observers or will they be segregated? Will Syria become a partitioned or federalized state? The de-escalation zones could be seen as a broader Russian effort to satisfy Turkey. The Russian-Turkish rapprochement may signal a broadening of relations. When asked about SCO membership, Turkish President Erdoğan replied, “[Turkey] shouldn't say, 'I'm for the EU no matter what.' ... For example, why shouldn't Turkey be part of the Shanghai Five [SCO]?" (Chulkovskaya, 2017). The Turkish president's answer or lack thereof highlights that SCO's possibility to provide a favorable alternative Washington's status quo.

\footnotetext{
${ }^{41}$ Specifically mentioned is the "elimination of DAESH/ISIL, Nusra Front and all other individuals, groups, undertakings and entities associated with Al-Qaeda or DAESH/ISIL" (The Ministry of Foreign Affairs Republic of Kazakhstan, 2017).
} 


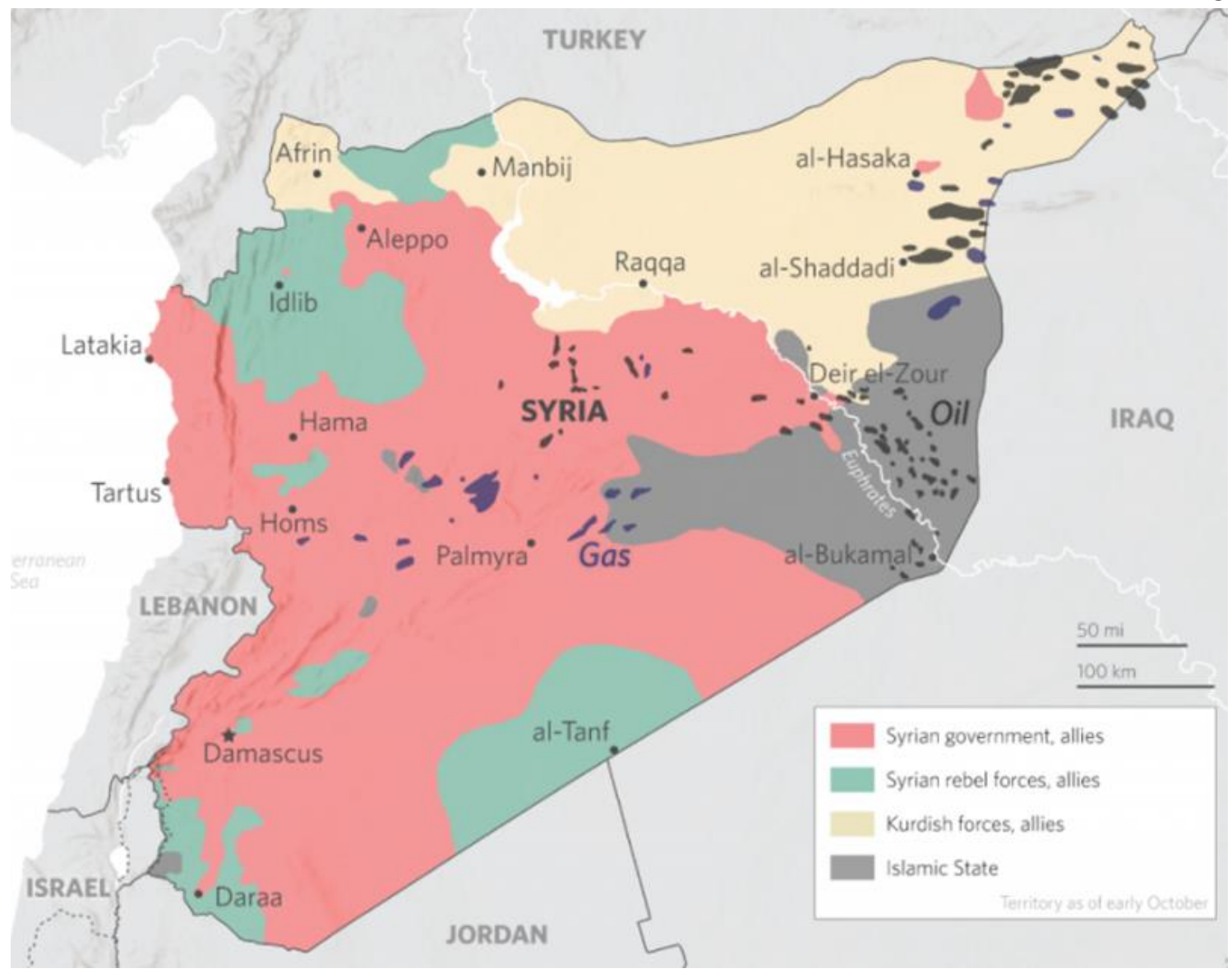

Figure 4 Map amended from original found at Stratfor (2017) 


\section{Chapter 6: Dyads after the Battle for Aleppo}

\section{Russia to Syria}

In 2017, Moscow and Damascus agreed to conditions that included the modernizing of Russia's naval facility in the Syrian port of Tartus expanding upon the already existing 2015 agreement (Nordland, 2017). The naval facility in Tartus will berth 11 ships simultaneously and Russia will send additional experts to train, "Syrian specialists in the restoration of the technical readiness of Syrian warships" (Global Security, 2017 ). The 2017 agreement will be enforced for 49 years and renewed every 25 years thereafter should neither side object. Similar stipulations will govern the Khmeimim airbase built by the Russians in 2015 (Nordland, 2017).

As of August of 2017, Operations Directorate Colonel-General Sergei Rudskoi disclosed that, "Since the beginning of the military operation, the Aerospace Forces have made more than 28,000 sorties, delivering around 90,000 airstrikes" (TASS, 2017). Rudskoi told reporters that, "During the operation of the Russian Aerospace Force, the territory controlled by the governmental forces, grew by more than four times - from 19 to 78 thousand square kilometers" (TASS, 2017). To help pacify the reclaimed Syrian territory, Russia initiated programs with villages that exchanges an end of hostilities (toward the regime) for "economic aid that includes hot meals and staple goods, and their farmers are permitted to leave the villages and tend their crops" (Bar'el, 2016). The recovery of Syrian terrain also means, "Russia will have at least partial access to approximately 50.5 bcms/year of natural gas exports, 5.5 times more than all of Syria's reserves and approximately 27 percent of Russia's annual LNG exports" (Sogoloff, 2017). 
Russia to Iran

Many observers label the Russia-Iran alliance as a "marriage of convenience".

The two nations have different ideological backgrounds but manage to unite to keep Syria from falling into the US status quo. Analysis conducted by the Institute for the Study of War concludes that, "Iran and Russia have largely stabilized the Assad regime" adding that the regime is more "secure in his continued rule now than at any point in the past four years" (Kagan, et al., 2017, p. 21). To complete that task, Russian and Iranian officials increased their ties and capabilities through shared intelligence and weapons sales ${ }^{42}$. The Institute for the Study of War claims that the most important function Iran provides for Russia, in Syria, is security. In return for ground troops, Russian power allowed for Iran to occupy Syrian territory and take part in the negotiation process. The Astana Agreement's de-escalation zones permitted Iran to secure access to Lebanese Hezbollah and position its proxies in the Golan Heights (Kagan, et al., 2017, p. 21).

Nonetheless, Russia and Iran are still divided on some key issues. Mclnnis suggests that Shia proxies that adhere to Iran's revolutionary ideology will likely be concerned with the nature of the Syrian regime. Similar to Lebanese Hezbollah, "The ideological and religious mission of Iranian proxies brings them in close contact with Iran's clerical establishment, as the IRI proselytizes its version of Shia Islamic thought" (Mclnnis, 2016). Russian objectives in Syria diverge from Iran's revolutionary aims.

\footnotetext{
${ }^{42}$ Sometime in 2016 Russia began supplying the Iranian regime with S-300 air defense missile and other advanced weapons systems (Katz, 2016, p. 5).
} 
According to Akbar Ganji five grievances persist including:

1) Russia's failure to veto UN Security Council resolutions against Iran over the nuclear issue; 2 ) the lengthy delay in Russian completion of the Bushehr nuclear reactor; 3) Russia's failure to sell weapons (including fighter aircraft, tanks, and various missiles) that Gorbachev said Moscow would sell to Tehran; 4) Russian pursuit of aims in Syria "which may sometimes be against Iran's;" and 5) Russia's close relations with "Iran's archenemies," Israel and Saudi Arabia (Katz, 2016, p. 6).

\section{Iran to Syria}

Iran's first goal in Syria was to ensure the survival of the Assad Regime. Iranian and Syrian authorities consistently vocalize their opposition to expanded American presence in the region and are motivated by their vileyat e faqih ideology ${ }^{43}$ (Mclnnis, 2016). Speaking to The Washington Post, former CIA acting director John McLaughlin states, "With about 7,000 troops in Syria, and coordination of thousands of militia fighters, Iran has taken over 1,000 casualties and established a firm foothold" (Rubin, 2017). With Assad firmly in power, Iranian chief of staff, Gen. Mohammad Hossein Bagheri arrived in Damascus in October of 2017 to discuss a list of Iranian objectives in Syria. These include a, "50-year lease on a Mediterranean naval base, the establishment of air bases on Syrian soil, phosphate mining concessions including for uranium, and so on" (Issacharoff, 2017). Recent reports indicate that IRGC General Mohammad Ali Jafari that Iran is pressuring the Assad regime to grant official status to the National Defense

\footnotetext{
${ }^{43}$ Iranian Revolution's ideology of "vileyat e faqih or guardianship of the jurisprudent, and recognizes the Iranian supreme leader as its ultimate religious and political authority" (McInnis, 2016). The vileyat e faqih ideology provides a mechanism to extract resources from the local population, possibly extending the Islamic republic's political capacity. Many in the Iranian leadership address the IRGC fighters and its Shia proxies in Syria as "defenders of the shrine". The shrine refers to the Sayyidah Zeinab Mosque an important place for Shia worship. The desecration of the mosque and other Shia shrines inflamed the importance of the Iranian population. According to The Washington Post, "89 percent of the Iranian public supports defending Shiite religious sites as an objective of Iran's policy in Syria" (Asadzade, 2017).
} 
Forces (NDF), Syria's main IRGC-created militia ${ }^{44}$ (Nadimi, 2017). Nadimi argues that, "If the NDF is formalized and becomes the main beneficiary of postwar Iranian military aid to Syria, Tehran would hold major leverage over how Damascus uses some of its most capable armed forces" (Nadimi, 2017). Iranian demands, reports The Times of Israel, were met in Damascus with skepticism. However, considering the heavy causalities Iran and its proxies endured the last six years these demands are realistic.

In late 2016, Mohammadali Shahidi Mahallati, head of Iran's Foundation of Martyrs, claimed Iranian casualties surpassed 1,000 fatalities (Sharafedin, 2016). By October of 2017 Iran's Martyrs Foundation, places that number north of 2,100 including 39 generals of the IRGC (Asadzade, 2017). Hezbollah's causalities include, "2,000 to 2,500 killed and some 7,000 injured over the last six years" (Alami, 2017).

\section{Turkey to Syria}

According to Lund, the Russian intervention had Erdoğan scrambling for “pragmatic solutions for Turkey's border woes” (Lund, 2017). During the battle for Aleppo, Turkey began deferring fighters from Aleppo City to the Kurdish corridor. Speaking to reporters, a senior official of the Sultan Murad Brigade told Reuters, "After leaving Aleppo, his group will join Turkey's Euphrates Shield operation" (Tastekin, 2016). "Some of them accuse Turkey of eroding their manpower by recruiting Free Syrian Army militants for its campaign against the Syrian regime, hence blaming Turkey for the loss

\footnotetext{
${ }^{44}$ On November 23, he stated, "It is up to the Syrian government to officialize the NDF or not, and we cannot force them to do so. In Iraq, they officialized al-Hashd al-Shabi and they're very grateful for that...Now the Syrian government and parliament must sign into law and officialize the Syrian version of al-Hashd al-Shabi" (Nadimi, 2017)
} 
of Aleppo" (Tastekin, 2016). Other militants made similar statements. Speaking to Sam Heller in Gaziantep, Al-Sheikh Jumu'ah (nom du guerre), a commander in the Levant Front, stated that "In the northern countryside, there's no bombing," adding the, "Area has become a sort of Turkish protectorate, politically" (Heller, 2017). Haaretz reported that the FSA was absent in most of Syria by the end of 2016, perhaps because of Turkish recruitment (Bar'el, 2016)

In February of 2017, US, Saudi and Turkish intelligence gave an ultimatum to fighters in Idlib: join a workable front or the "joint operations center would cut off assistance, which included fighters' salaries, light weapons, ammunition and anti-tank missiles" (Tastekin, 2017). Seventeen organizations pledged to form a new coalition, yet Turkey worked simultaneously to form partnerships with various independent groups in Idlib (Tastekin, 2017). Turkish troops arrived in Idlib province, in accordance with the Astana Agreement, on October $13^{\text {th }}$. However, Turkish actions suggests Ankara has other motives.

Al-Monitor reports that 100 Turkish commandos crossed the border into Idlib at night with equipment to build 14 observation outposts. The commandos quickly claimed the Sheikh Barakat, an 842-meter-high (2,762-foot-high) mountain giving the Turkish Armed Forces (TSK), the capability of reaching Kurdish enclave of Afrin (Gurcan, 2017). Turkish actions have raised suspicions of whether Turkey intends on stabilizing Idlib or attacking Kurdish interests. The TSK has reportedly given Hayat Tahrir al-Sham (Salafist radical group) in Idlib the three options: one, fighters must disarm if wish to stay in Idlib; two, fighters can join the FSA; three, fighters can transfer to the Operation Euphrates 
Shield theater in Al-Bab (Gurcan, 2017). But, granting Hayat Tahrir al-Sham the option of integrating with the FSA, comprised of 60 factions with no central command ${ }^{45}$, gives Turkey an easy cover to interact with Islamic extremists.

\section{Turkey to Iran}

Erdoğan's attempt to reorient Turkey to the Middle East initially ingratiated itself with regional actors, but Ankara's role in the Syrian Civil War placed Turkey at odds with Tehran (Yeşilada B. A., 2016, p. 24). When the fall of Aleppo was immanent, IranianTurkish relations began changing. Turkish planners began recruiting Sunni extremists from Jabhat Fatah al-Sham (formerly Jabhat al-Nusra) and sending the fighters to join Operation Euphrates Shield in the Azaz/Al-Bab region in Northern Syria (Tastekin, 2016). In a show of solidarity, Iranian militias aided the Turkish Army in the taking of al-Bab (AlKhalidi \& Butler, 2017). In the process, Russian airstrikes killed three Turkish troops (AlKhalidi \& Butler, 2017) and an Iranian drone killed four TSK soldiers (Erkuş, 2016). The incidents were acknowledged as accidents with no known repercussions by the governments involved.

Improved relations from the Turkish- Iranian rapprochement in the 2000 s proved to be a valuable asset to the Islamic Republic. At the height of the war in Syria, Iranian President Hassan Rouhani expressed support for Erdoğan during the failed coup attempt in July 15, 2016 (Karami, 2016). When hostilities in Syria heightened tensions among

\footnotetext{
${ }^{45}$ There are at least sixty-three different factions represented in the Free Syrian Army (FSA) and those factions are not unified (al-Khateb, 2017). The FSA consists of, "Six large militias, which are organized into brigades and battalions that operate in a number of areas in Syria without a central command" (Bar'el, 2016). These brigades are poorly coordinated and function as separate militias operating under different commanders and orders.
} 
ethnic divisions ${ }^{46}$ in both counties, provocations were met with calls for restraint and civility. Turkish Foreign Minister Mevlüt Çavuşoğlu emphasized cooperation with Iran to end the crisis in Syria upon his return from Tehran in late November of 2016 (Idiz, 2016).

As fighting diminishes commercial interest seem to be gaining momentum. A \$7 billion oil and gas deal between Turkey's Unit International, Russia's Zarubezhneft and Iran's Ghadir will drill for oil and gas in Iran. The Iranian fields will purportedly bring ten billion barrels to market at 100,000 barrels per day. The natural gas field has a believed production capacity of 75 billion cubic meters per year. To put that in context, Turkey imports 50 billion cubic meters of gas annually making the deal a lucrative proposition for Ankara. The Daily Sabah comments that this partnership "Is the first trilateral investment agreement between an Iranian company and foreign partners", a purported, "Milestone in the Iranian petrochemical industry" (Daily Sabah, 2017).

\section{Kurds-Turkey-US-Russia}

On August 24, 2016, Recep Tayyip Erdoğan announced that Turkish Forces commenced Operation Euphrates Shield against ISIS and the YPG "terror groups that threaten our country in northern Syria" (Agence France-Presse, 2016) (Ülgen \& Kasapoğlu, 2017). The TSK and FSA troops, aided by Russian and American airpower began the campaign in the Syrian town of Jarabulus which served ISIS's "main smuggling and trade hub in northern Syria" since taking the town in 2014 (Lund, 2016). The TSK moved west toward Dabiq then south to Al-Bab. The western move was seen as, "A

\footnotetext{
46 The riff became very pronounced with intense hatred among both nations. Iranian back militias harassing refugees leaving Aleppo and (Idiz, 2016).
} 
critical maneuver in hindering the efforts of the PKK terrorist organization, and its PYD/YPG [People's Protection Units (YPG)] affiliates, aimed at linking the eastern territories under their de facto control with Afrin in the west" (Ülgen \& Kasapoğlu, 2017). In late 2016, the Turkish Air Force carried out 26 strikes against YPG and Syrian Democratic Forces (SDF) ${ }^{47}$ fighters killing 160-200 around Afrin (Toksabay \& McDowall, 2016). Less than 30 miles from Aleppo, the Turkish Armed Forces (TSK) established a base in Al-Bab separating the Syrian Kurdish cantons (Petkova, 2017) (Ülgen \& Kasapoğlu, 2017).

US efforts to supply YPG and SDF fighters increased in recent years (Humud, Blanchard, \& Nikitin, 2017). In Turkey evidence emerged that 100 trucks packed will military equipment was being sent to YPG fighters (Hurriyet Daily News, 2017). Taking questions on Capitol Hill, former US Secretary of Defense Ashton Carter testified ${ }^{48}$ that the United States was indeed arming the YPG in Syria (C-SPAN, 2016). The US has denied reports of airbases in Rmeilan (located in the Hasaka governorate, northeast) and Kobani (on Turkish border south of Suruç) (Al-Khalidi, 2016), but acknowledges the presence of some 300 special operations troops in Syria operating in training and support roles mostly in Kurdish held areas (BBC News, 2016). Eyewitnesses in the region

\footnotetext{
47 "It is not clear how many fighters the SDF has deployed around Raqqa. However, the SDF has about 50,000 fighters in total, with Arabs making up about $60 \%$ of the force and Kurds $40 \%$, according to the coalition" (BBC News, 2017). Lund states, "The Syrian Democratic Forces, or SDF, is a coalition of Kurdish, Sunni Arab and Syriac Christian fighters, but is completely dominated by its Kurdish element, which is a powerful and well organized militia known as the Popular Defense Units, YPG, with an all-female branch called the Women's Defense Units, or YPJ. These organizations, in turn, are Syrian front groups for the Kurdistan Workers' Party or PKK" (Lund, Origins of the Syrian Democratic Forces: A Primer, 2016). ${ }^{48} \mathrm{Sec}$. Carter, answering Sen. Lindsay Graham, admits that PYD is affiliated with the PKK (Yahya, 2016) (CSPAN, 2016). https://www.c-span.org/video/?408675-1/secretary-carter-general-dunford-testify-isisstrategy questioning begins at 02:05:05.
} 
told reporters that "scores of U.S. experts and technicians were involved in the project" (Al-Khalidi, 2016). Tensions effervesced between the United States and Turkey when leaked photos of US special forces wearing YPG insignia prompted the Turkish Foreign Minister Mevlut Cavusoglu to call the "US 'two-faced' and said the practice was “unacceptable'” (BBC News, 2016).

In May of 2017, The Trump administration announced that the United States would continue to support YPG militants serving under the umbrella of the SDF (Gordon \& Schmitt, 2017). Shortly after the announcement, the SDF commenced a second offensive to capture Raqqa from ISIS fighters (BBC News, 2017). Backed by the United States, the SDF captured Raqqa on October 17, 2017 while Syrian government forces and their Russian, and Iranian allies, took Mayadeen southeast of Raqqa in the Deir alZour province (Barnard \& Saad, Raqqa, ISIS 'Capital,' Is Captured, U.S.-Backed Forces Say, 2017). Al Jazeera states, "The coalition is in a race against Russian-backed Syrian governments troops to seize parts of the resource-rich Deir Ar Zor province" (Al Jazeera, 2017). In March 2017, YPG spokesman Redur Xelil announced that the Kremlin and the YPG signed an agreement to establish a Russian base in Kafr Jina in the Afrin region of northwest Syria (Al Jazeera, 2017). The agreement will put Russian trainers in contact with YPG militants and enhance communications capabilities.

Perhaps because of victories in Iraq and Syria, Kurdistan Regional Government (KRG), based in Iraq, held a referendum on independence in September of 2017. 92 percent of Kurdish voters endorsed the establishment of an independent Kurdish state, splitting from Baghdad. The referendum aroused condemnation from surrounding 
countries including Turkey which threatened to close the boarders with Kurdistan

(Chulov, 2017). The move shows that with opportunity satisfaction can change. Just

three years earlier, "The Kurdistan Democratic Party [KDP] led by Massoud Barzani, strongly opposed the PYD's autonomy project in Syria" (Lawson, 2014, p. 1357).

Barzani's condemnation, more than likely, arose from an agreement negotiated

between the KRG and Ankara to provide 100,000 barrels of oil daily to Ceyhan (Lawson, 2014, p. 1357). The Guardian reports that bilateral trade between Turkey and the KRG is valued at more than $\$ 10$ billion annually (Chulov, 2017). The deals underscore the fact that Kurdistan is landlocked and its economy depends on oil exports making energyhungry Turkey a likely partner ${ }^{49}$.

$\underline{\text { Russia to Turkey }}$

A Russian-Turkish rapprochement appeared evident when both countries' downplayed ${ }^{50}$ the assassination of Russian ambassador Andrei Karlov as attempts to destabilize Russian-Turkish relations ${ }^{51}$. The Russian-Iranian victory in Aleppo firmly placed Russia at the Middle East hierarchy. Valdimir Putin declared, "The next step [after Aleppo] will be to reach agreement on a complete cease-fire across all of Syria.

\footnotetext{
${ }^{49}$ The environment and lack of cohesion means lucrative opportunities can arise. Many times, Kurds have entered into cooperative relations and enterprise with regional governments. Current Iraqi President Fuad Masum, a Kurd from the PUK party (rival to the KDP), condemned the KRG's referendum and sent Iraqi troops to fight Kurdish Peshmerga fighters in Kirkuk (Florence, 2017). It also should be noted that two former Turkish Presidents İsmet İnönü and Turgut Özal were of Kurdish descent.

${ }^{50}$ Commenting on the Karlov murder, Erdoğan said, "We know that this is a provocation aiming to destroy the normalization process of Turkey-Russia relations" (Arango \& Gladstone, 2016). Putin labeled the assassination, "provocation aimed at rupturing ties between Russia and Turkey" (Filipov, Fahim, \& Sly, 2016).

${ }^{51}$ It should be noted that Karlov was the Russian ambassador to Turkey and was murdered by Turkish security guard on Turkish soil.
} 
We are actively negotiating with members of the armed opposition, with the mediation of Turkey'" (Tastekin, 2016).

Moscow's desire to stabilize Syria led Russian policymakers to take a hands-off approach to Idlib. Abdicating Idlib and Al-Bab to Turkey likely occurred because of regional opposition to an independent Kurdistan. Ankara's involvement in Idlib and AlBab effectively prevents Kurdish access the Mediterranean Sea, but leads to Turkey's continued involvement with extremist groups because of the unlikelihood of the FSA to organize ${ }^{52}$. Further testing US and NATO resolve, Turkey agreed to purchase two Russian S-400 missile batteries for $\$ 2.5$ billion dollars in August of 2017 (BBC News, 2017).

Turkey's acquiescence to Russian order places Ankara in both the western and eastern status quos. Yeşilada points out that the liberal international order views Ankara's interaction suspiciously and with contempt (Yeşilada B. A., 2016, p. 24). To destroy ISIS, Washington has partnered with Kurdish militias. Although the United States' ISIS strategy appears successful (with the ISIS expulsion from Syrian territory first), US cooperation with the YPG/SDF provoked Erdoğan to threaten American access to the Incirlik Air Base (Cook, 2017).

\footnotetext{
52 Al-Monitor reports that, "The coordinator of the FSA factions, Yahya Mayo, confirmed that 44 FSA factions out of 63 have announced their willingness to join the ranks of the unified national army" (alKhateb, 2017).
} 


\section{Chapter 7: Conclusion}

First, a note on the research method I have utilized. No concise data set exists on the Syrian Civil War. Statistical analysis would likely provide more samples and reduce the margin of error. Survey questions would likely include a Likert scale. Testing results could place satisfaction on a spectrum to better estimate probability of conflictcooperation between dyadic relationships. It is unfortunate Syrian Civil War data does not exist. That said, empirical occurrences provided valuable takeaways.

The original question posed: Is Power Transition Theory, using data from the Syrian Civil War, capable of providing a regional hierarchal analysis with predictive value? The answer is yes. First, Iran, Russia, and Turkey were verifiably present on the Syrian battlefield. The hierarchs not only participated in the Syrian Civil War but Iran, Russia, and Turkey are party to the Astana Agreement, which forces them to send observers to Syria. Second, Syria was an anarchic environment. Numerous countries and militias operating within Syria attest to the Assad regime's inability to exercise authority over its territory. Third, state actors interacted with non-state actors in hostile and cooperative capacities. The non-state actors in Syria share the same characteristics that made the APEs of the Rio de la Platte compatible with PTT analysis. The SDF/PYD and FSA signed agreements with Russia and the United States, have battle flags, territory and, in some cases, govern. These non-state actors could be incorporated into the regional hierarchy and add to the power dynamics of coalitions. 


\section{Middle East Hierarchy}

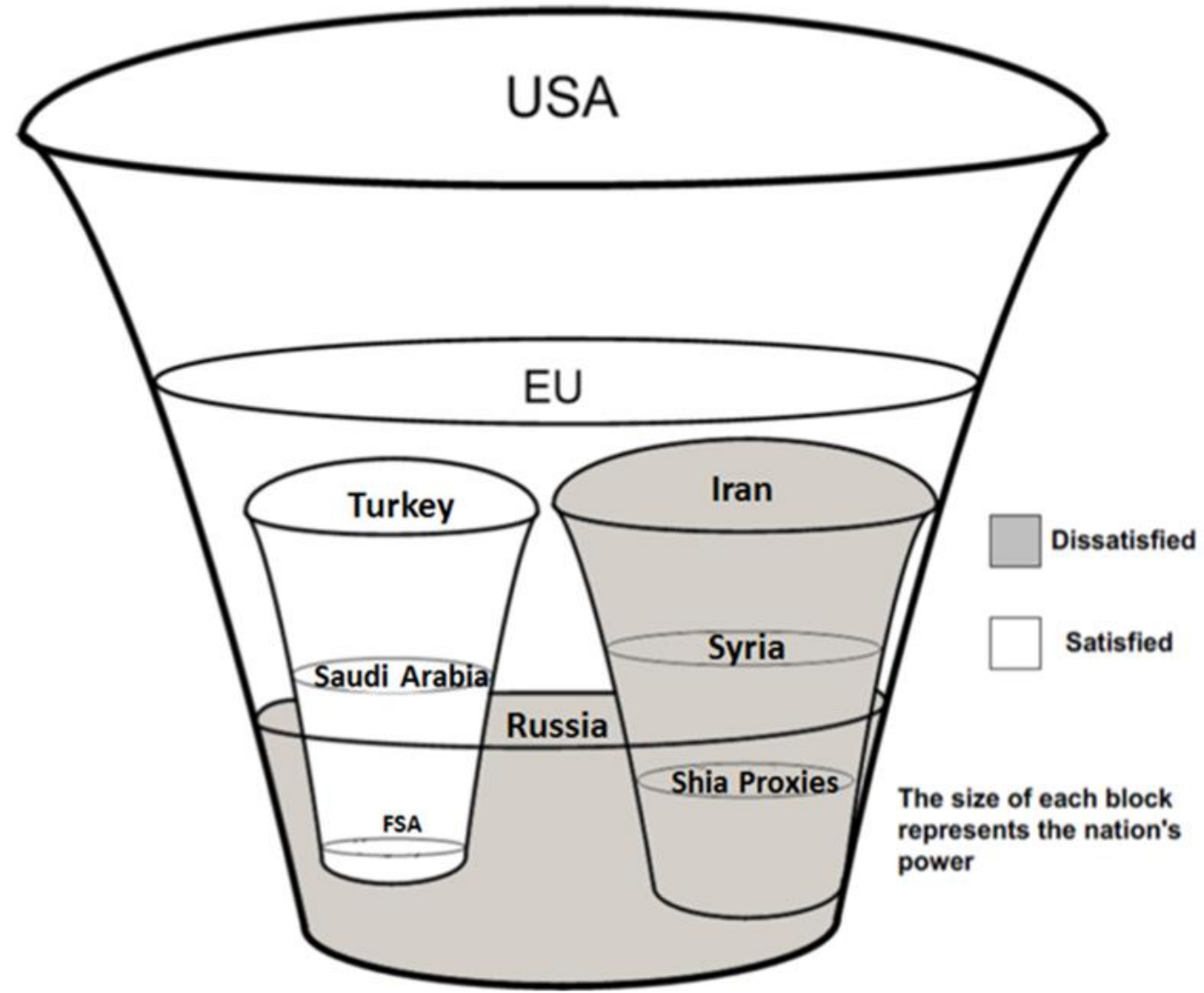

Figure 5 Middle East Hierarchy updated from (Tammen, Kugler, \& Lemke, 2011)

In regards to power, the United States' intervention in Syria altered the civil

war's outcomes. This was accomplished by partnering with SDF fighters to extend the status quo east of the Euphrates River. Regionally, Yeşilada and Tanrikulu's 2016 findings appear vindicated. Their analysis placed Russia first in the Middle East's hierarchy with Turkey and Iran following at near parity. Throughout the conflict, Russia remained the region's preponderant nation exceeding the Turkish economy by over a trillion dollars. As a dissatisfied actor, Russia challenged regional status quo by supporting other regional dissatisfied actors. Figure 5 shows the regional hierarchy, incorporating Kim's alliance metric, the power garnered by Moscow's Aerospace Forces 
and competent Iranian grounds forces surpassed the disorganized Sunni opposition. It comes as no surprise that the Astana Agreement's guarantor countries (Iran, Russia, and Turkey) stand to benefit the most from actions in Syria west of the Euphrates River.

Russia now has a strong foothold in the Middle East, its own port on the Mediterranean, and the possibility to cultivate its regional economic interests. Iran maintains a key Shia (Alawite) ally in the region and continues to have overland access to Lebanon, thus preserving Iranian access to the Mediterranean. Both Russia and Iran stand to gain from Syria's valuable location as transit country for Middle East fossil fuels to European consumers. East of the Euphrates River, similar incentives exist for the United States, however, the US role in Syria aims at servicing the status quo not altering the order. Turkey remains a valuable asset to both respective orders in the region because of its geostrategic location, NATO member status, and role as funder and supplier to dissident groups. The threat of moving away from convergence towards dissatisfaction allows Turkey to leverage its dispositions for more favorable terms within the status quo. Iran and Russia's intent to challenge US order in the region have led the alliance to cadre to Turkish grievances.

Turkey's main priority is to secure the southern border and deter Kurdish autonomy. Moscow addressed Erdoğan's concern by including Idlib into the Astana Agreement's de-escalation zones. TSK's commandos operating in Idlib and Ankara's cooperation with Islamic extremist groups are intended to block Kurdish access to the Mediterranean. Outside of the Astana Agreement, the Turkish base in Al-Bab aims at dividing Kurdish attempts to unify the Kurdish cantons of Afrin and Kobani. To further 
secure the southern border from aircraft, Russia sold two S-400 missile batteries to Turkey. The S-400 missile batteries presumably have the same, or similar, capabilities as the batteries deployed at the Khmeimim airbase. This means that Russian jets, which have previously been shot down by Turkey, will be subject to Russia's own advanced anti-aircraft system. The sale suggests that Turkish and Russian governments have achieved a new level of trust. By incorporating Russian defense technology Turkey steps further from an already strained relationship with NATO. Second, Erdoğan's authoritarian measures in domestic governance and alliance with extremist groups diverges American-Turkish relations. If Turkey continues to show signs of dissatisfaction, Russian ambivalence versus the American status quo could likely appeal more to Ankara. But, Moscow and Ankara run the risk of a broader US intervention if their actions challenge Washington's interests in the region.

In an attempt to reorient its foreign policy to the east, Turkey may have taken to Russia's indifferent approach to governance, but the Russian order may place the Kremlin at odds with Tehran. Russia's readiness to end fighting suggests Putin is more interested in establishing and restoring commercial ties than exporting the Iranian Revolution ${ }^{53}$. Iran's patterns of interaction in Syrian Civil War suggest that the Islamic Republic is determined to export the vileyat e faqih ideology. If Iran acquires a nuclear

\footnotetext{
53 "Moscow has no wish to be part of an Iranian pro-Shia camp confronting the GCC [Gulf Cooperation Council]-led Sunni coalition. This would affect Russian security as its Muslim population of 15 million is largely Sunni. Salafi groupings in the Gulf have depicted Russians as new crusaders since the beginning of the civil war in Syria. In October 2015, Moscow received a warning when approximately 50 Saudi clerics signed an open declaration calling for jihad against Moscow." (Kozhanov, 2016, p. 4).
} 
weapon the dynamics of the region will change ${ }^{54}$. PTT regards the most dangerous

nation as "the fast-growth dissatisfied challenger that acquires nuclear weapons" within a hierarchy (Tammen, et al., 2000, p. 97). Iranian possession of a nuclear weapon

disrupts Israel's regional nuclear preponderance. As we have seen, nations within parity prelude the onset of hostilities and, in this case, would likely lead to nuclear proliferation across the Middle East and ensuing hostilities.

54 PTT regards nuclear proliferation different from classical deterrence. Power Transitions: Strategies for the 21st Century maintains that "Nuclear preponderance in the hands of a satisfied defender produces stability, while in the hands of a dissatisfied challenger the outcome is unstable" (Tammen, et al., 2000, p. 91). For thorough analysis see Power Transitions: Strategies for the 21st Century pages 82-106. 


\section{Works Cited}

Abedin, M. (2017, April 3). Tensions in Russia-Iran ties. Retrieved from Middle East Monitor: https://www.middleeastmonitor.com/20170403-tensions-in-russiairan-ties/

Agence France-Presse. (2016, August 24). Erdogan says Syria operation aimed at IS jihadists, Kurdish PYD. Retrieved from Daily Mail: http://www.dailymail.co.uk/wires/afp/article-3756119/Erdogan-says-Syriaoperation-aimed-IS-jihadists-Kurdish-PYD.html

Al Arabiya. (2012, June 22). Turkey confirms Syria shot down F-4 military jet, search for pilots ongoing. Retrieved from Al Arabiya:

http://english.alarabiya.net/articles/2012/06/22/222135.html

Al Jazeera. (2016, July 7). Syria: Army cuts strategic Aleppo road despite truce. Retrieved from Al Jazeera: http://www.aljazeera.com/news/2016/07/syria-army-cutsstrategic-aleppo-road-truce-160707135549560.html

Al Jazeera. (2017, October 22). SDF says it captured al-Omar oilfield from ISIL. Retrieved from Al Jazeera: http://www.aljazeera.com/news/2017/10/sdf-captured-alomar-oil-field-isil-171022194321039.html

Al Jazeera. (2017, March 20). Syrian Kurds say Russia to build base in Afrin. Retrieved from Al Jazeera: http://www.aljazeera.com/news/2017/03/russia-strikes-dealsyrian-kurds-set-base-170320142545942.html

Al Jazeera. (2017, February 19). Timeline of attacks in Turkey. Retrieved from Al Jazeera: http://www.aljazeera.com/indepth/interactive/2016/06/timeline-attacksturkey-160628223800183.html

Alami, M. (2017, March 28). Will Hezbollah Remain in Syria Forever? Retrieved from Newsweek: http://www.newsweek.com/will-hezbollah-remain-syria-forever573818

Albert, E. (2015, October 14). The Shanghai Cooperation Organization. Retrieved from Council on Foreign Relations: https://www.cfr.org/backgrounder/shanghaicooperation-organization

Al-Khalidi, S. (2016, March 6). U.S. builds two air bases in Kurdish-controlled north Syria: Kurdish report. Retrieved from Reuters: http://www.reuters.com/article/usmideast-crisis-syria-usa-base-idUSKCNOW80R7

Al-Khalidi, S., \& Butler, D. (2017, February 9). Russian bombing in Syria mistakenly kills three Turkish soldiers. Retrieved from Reuters: 
https://www.reuters.com/article/us-mideast-crisis-syria-albab/russian-bombingin-syria-mistakenly-kills-three-turkish-soldiers-idUSKBN150100

al-Khateb, K. (2017, September 15). Divided Syrian opposition tries for unified army again. Retrieved from Al-Monitor: https://al-

monitor.com/pulse/originals/2017/09/syria-opposition-fsa-unified-nationalarmy.html

Al-Monitor. (2012, July 10). Former Syrian Officer Says Ranks of Defectors Are Swelling. Retrieved from Al-Monitor: http://www.al-monitor.com/pulse/security/01/07/adissident-alawi-army-officer-a.html

Apuzzo, M., \& Mazzetti, M. (2016, Janurary 23). U.S. Relies Heavily on Saudi Money to Support Syrian Rebels. Retrieved from The New York Times: https://www.nytimes.com/2016/01/24/world/middleeast/us-relies-heavily-onsaudi-money-to-support-syrian-rebels.html

Arango, T., \& Gladstone, R. (2016, December 19). Russian Ambassador to Turkey Is Assassinated in Ankara. Retrieved from The New York Times: https://www.nytimes.com/2016/12/19/world/europe/russia-ambassador-shotankara-turkey.html

Arbetman-Rabinowitz, M., Group, S., \& Johnson, K. (2007). Relative Political Capacity: Empirical and Theoretical Underpinnings. Paper presented at Claremont Graduate University, Claremont, CA, 1-16. Retrieved from https://pdfs.semanticscholar.org/68ae/6f8fb1a13db0914446477f17ba57f9aaa29 2.pdf

Asadzade, P. (2017, October 19). Iran's involvement in Syria is costly. Here's why most Iranians still support it. Retrieved from The Washington Post: https://www.washingtonpost.com/news/monkey-cage/wp/2017/10/19/iransinvolvement-in-syria-is-costly-heres-why-most-iranians-still-supportit/?utm_term=.b1b9068b30ed

Bar'el, Z. (2016, November 26). The Free Syrian Army Follows Orders From Turkey. Retrieved from Haaretz: https://www.haaretz.com/middle-east-news/.premium1.755348

Barnard , A., \& Saad, H. (2017, October 17). Raqqa, ISIS 'Capital,' Is Captured, U.S.Backed Forces Say. Retrieved from The New York Times: https://www.nytimes.com/2017/10/17/world/middleeast/isis-syria-raqqa.html

BBC News. (1999, July 19). Turkey denies Iran 'airstrike' . Retrieved from BBC News: http://news.bbc.co.uk/2/hi/middle_east/398409.stm 
BBC News. (2013, December 13). Guide to the Syrian rebels. Retrieved from BBC News: http://www.bbc.com/news/world-middle-east-24403003

BBC News. (2013, May 25). Hezbollah leader Nasrallah vows victory in Syria. Retrieved from BBC News: http://www.bbc.com/news/world-middle-east-22669230

BBC News. (2015, December 1). Turkey's downing of Russian warplane - what we know. Retrieved from BBC News: http://www.bbc.com/news/world-middle-east34912581

BBC News. (2016, May 27). Syria war: Turkey anger over US commando photos. Retrieved from BBC News: http://www.bbc.com/news/world-middle-east36396248

BBC News. (2016, March 11). Syria: The story of the conflict. Retrieved from BBC News: http://www.bbc.com/news/world-middle-east-26116868

BBC News. (2017, June 6). Raqqa: Syrian Kurdish-led forces launch offensive on IS 'capital'. Retrieved from BBC News: http://www.bbc.com/news/world-middleeast-40171406

BBC News. (2017, September 12). Turkey signs deal to get Russian S-400 air defence missiles. Retrieved from BBC NEws: http://www.bbc.com/news/world-europe41237812

Birnbaum, M. (2016, January 15). The secret pact between Russia and Syria that gives Moscow carte blanche. Retrieved from The Washington Post : https://www.washingtonpost.com/news/worldviews/wp/2016/01/15/thesecret-pact-between-russia-and-syria-that-gives-moscow-carteblanche/?utm_term=.76969346c4a0

Bora, B. (2017, February 26). What is behind the hostility between Iran and Turkey? Retrieved from Al Jazeera:

http://www.aljazeera.com/indepth/features/2017/02/hostility-iran-turkey170225184418231.html

British Petroluem. (2017). Baku-Tbilisi-Ceyhan pipeline. Retrieved from British Petroluem: http://www.bp.com/en_az/caspian/operationsprojects/pipelines/BTC.html

Broad, W. J., \& Mazzetti, M. (2007, October 26). Photos Show Cleansing of Suspect Syrian Site. Retrieved from The New York Times: http://www.nytimes.com/2007/10/26/world/middleeast/26syria.html

Brooks, S. G. (1997). Dueling Realisms. International Organization, 445-477. 
Buszynski, L. (2005). Russia's New Role in Central Asia. Asian Survey, 546-565.

Carkoglu, A., Eder, M., \& Kirisci, K. (1998). The Political Economy of Regional Cooperation in the Middle East. London: Routledge.

Chulkovskaya, Y. (2017, January 9). Will Turkey leave NATO? Retrieved from Al-Monitor: https://www.al-monitor.com/pulse/originals/2017/01/russia-turkey-erdoganputin-membership-shanghai-sco-eu.html

Chulov, M. (2017, September 26). Iraq: Kurdish leader Barzani claims win in independence referendum. Retrieved from The Guardian: https://www.theguardian.com/world/2017/sep/26/iraq-kurdish-leader-barzaniclaims-win-in-independence-referendum

Chulov, M. (2017, September 27). More than 92\% of voters in Iraqi Kurdistan back independence. Retrieved from The Guardian: https://www.theguardian.com/world/2017/sep/27/over-92-of-iraqs-kurds-votefor-independence

Cook, S. A. (2017, October 12). The American Alliance With Turkey Was Built On a Myth. Retrieved from Foreign Policy: http://foreignpolicy.com/2017/10/12/theamerican-alliance-with-turkey-was-built-on-a-myth/

C-SPAN. (2016, April 28). U.S. Strategy Against ISIS. Retrieved from C-SPAN: https://www.c-span.org/video/?408675-1/secretary-carter-general-dunfordtestify-isis-strategy

Cunningham, D. E., \& Lemke, D. (2013). Combining Civil and Interstate Wars. International Organization, 609-627.

Daily Sabah. (2017, August 15). Turkish, Russian, Iranian companies ink \$7B energy deal. Retrieved from Daily Sabah: https://www.dailysabah.com/energy/2017/08/16/turkish-russian-iraniancompanies-ink-7b-energy-deal

Daniels, J. (2017, September 12). US relays concern to Turkey after NATO ally makes deposit to buy Russian defense system. Retrieved from CNBC: https://www.cnbc.com/2017/09/12/us-turkish-ties-continue-to-deteriorate.html

Davison, J. (2017, October 17). Raqqa: Isis completely driven out of Syria 'capital' by USbacked forces. Retrieved from The Independent : http://www.independent.co.uk/news/world/middle-east/raqqa-isis-battle-syriadefeat-latest-lost-us-sdf-rebel-monitoring-group-a8004581.html 
DeYoung, K. (2017, July 24). Cooperation with Russia becomes central to Trump strategy in Syria. Retrieved from Washington Post:

https://www.washingtonpost.com/world/national-security/cooperation-withrussia-becomes-central-to-trump-strategy-in-syria/2017/07/24/ba6172be-6e3811e7-9c15-177740635e83_story.html?utm_term=.9809e326b8e9

Doyle, M. W. (1986). Liberalism and World Politics. The American Political Science Review, 1151-1169.

Eligür, B. (2010). The Mobilization of Political Islam in Turkey. Cambridge: Cambridge University Press.

Entous, A. (2015, January 26). Covert CIA Mission to Arm Syrian Rebels Goes Awry. Retrieved from Wall Street Journal: https://www.wsj.com/articles/covert-ciamission-to-arm-syrian-rebels-goes-awry-1422329582

Erkuş, S. (2016, December 7). Iranian-made drone involved in attack on Turkish soldiers in Syria. Retrieved from Hürriyet Daily News:

http://www.hurriyetdailynews.com/iranian-made-unmanned-drone-involved-inattack-on-turkish-soldiers-in-

syria.aspx?PagelD=238\&NID=106965\&NewsCatID=352

European Commission. (n.d.). Supplier countries. Retrieved 2017, from European Commission: https://ec.europa.eu/energy/en/topics/imports-and-securesupplies/supplier-countries

Filipov, D., Fahim, K., \& Sly, L. (2016, December 19). Turkish police officer, invoking Aleppo, guns down Russian ambassador in Ankara. Retrieved from The Washington Post: https://www.washingtonpost.com/world/gunfire-woundsrussian-ambassador-in-turkey-reports-say/2016/12/19/ae32d1c8-c608-11e685b5-76616a33048d_story.html?utm_term=.360fb074ea0a

Filkins, D. (2013, September 30). The Shadow Commander. Retrieved from The New Yorker: http://www.newyorker.com/magazine/2013/09/30/the-shadowcommander

Fisunoğlu, A. (2016, August). Conflict and Cooperation in the Northern Middle East from a Power Transition Theory Perspective. Carmel, California, United States of America.

Flanagan, S. J. (2013). The Turkey-Russia-Iran Nexus: Eurasian Power Dynamics. The Washington Quarterly, 163-178. 
Florence, R. (2017, October 19). 'The Kurdish regional government is at an impasse'. Retrieved from France 24: http://www.france24.com/en/20171019-iraq-kurdsregional-government-impasse-kurdistan-referendum-kirkuk-puk-kdp-marcou

Frontline. (2011, November 7). The Regime. (M. Gaviria, Producer, \& A Frontline production with RAINmedia) Retrieved from PBS: http://www.pbs.org/wgbh/frontline/film/the-regime/

Garamone, J. (2017, April 6). Trump Orders Missile Attack in Retaliation for Syrian Chemical Strikes. Retrieved from U.S. Department of Defense: https://www.defense.gov/News/Article/Article/1144601/trump-orders-missileattack-in-retaliation-for-syrian-chemical-strikes/

Global Security. (2017 ). Russian Naval Base at Tartus / Tartous. Retrieved from Global Security: http://www.globalsecurity.org/military/world/syria/tartous.htm

Gordon, M. R., \& Schmitt, E. (2017, May 9). Trump to Arm Syrian Kurds, Even as Turkey Strongly Objects. Retrieved from The New York Times: https://www.nytimes.com/2017/05/09/us/politics/trump-kurds-syriaarmy.html?_r=2

Gresh, G. F. (2009). Iranian Kurds in an Age of Globalisation. Iran \& the Caucasus,, 187196.

Gurcan, M. (2017, October 17). Turkey's return riles Syria: It's 'blatant aggression'. Retrieved from Al-Monitor: https://www.almonitor.com/pulse/originals/2017/10/turkey-syria-what-ankara-has-in-mindfor-afrin-idlib.html

Gürel, A., \& Tzimitras, H. (2015). Beyond Energy: Remarks about the Direction of Turkish-Russian Relations and Their Implications for the Cyprus Problem. Energy and Integration In the Black Sea Region, 28-38.

Gurses, M. (2015). Transnational Ethnic Kin and Civil War Outcomes. Political Research Quarterly,, 142-153.

Hacaoglu, S. (2017, July 13). Turkey Chooses Russia Over NATO for Missile Defense. Retrieved from Bloomberg: https://www.bloomberg.com/news/articles/201707-13/turkey-is-said-to-agree-to-pay-2-5b-for-4-russian-s-400-sams

Harris, G. (2017, April 11). Tillerson Warns Russia on Syria, Saying Assad Era Is 'Coming to an End'. Retrieved from The New York Times: https://www.nytimes.com/2017/04/11/world/europe/russia-syria-rextillerson.html 
Heller, S. (2017, April 12). Turkey's "Turkey First" Syria Policy. Retrieved from The Century Foundation: https://tcf.org/content/report/turkeys-turkey-first-syriapolicy/\#easy-footnote-bottom-7

Herszenhorn, D. M. (2012, February 19). For Syria, Reliant on Russia for Weapons and Food, Old Bonds Run Deep. Retrieved from The New York Times: http://www.nytimes.com/2012/02/19/world/middleeast/for-russia-and-syriabonds-are-old-and-deep.html

Hitchens, C. (2008). DEAR MR. PRESIDENT ... On Sovereignty. World Affairs, 6-11.

Hof, F. (2015, October 14). I Got Syria So Wrong. Retrieved from Politico: http://www.politico.com/magazine/story/2015/10/syria-civil-war-213242

Hosenball, M. (2012, August 1). Exclusive: Obama authorizes secret U.S. support for Syrian rebels. Retrieved from Reuters: http://www.reuters.com/article/us-usasyria-obama-order-idUSBRE87010K20120801

Hubbard, B. (2016, December 22). Turning Point in Syria as Assad Regains All of Aleppo. Retrieved from The New York Times: https://www.nytimes.com/2016/12/22/world/middleeast/aleppo-syriaevacuation.html

Humud, C. E., Blanchard, C. M., \& Nikitin, M. D. (2017, October 13). Armed Conflict in Syria: Overview and U.S. Response. Retrieved from Federation of American Scientists: https://fas.org/sgp/crs/mideast/RL33487.pdf

Hurriyet Daily News. (2017, May 23). US dispatches 100 trucks packed with military equipment to YPG. Retrieved from hurriyetdailynews: http://www.hurriyetdailynews.com/us-dispatches-100-trucks-packed-withmilitary-equipment-to-ypg.aspx?pageID=238\&nID=113445\&NewsCatID=352

Idiz, S. (2016, December 20). Animosity toward Iran reaches fever pitch in Turkey after Aleppo. Retrieved from Al-Monitor: https://www.almonitor.com/pulse/originals/2016/12/turkey-iran-animosity-reaches-feverpitch.html

IEA. (2017). Key World Energy Statistics 2017. Retrieved from IEA: http://www.iea.org/publications/freepublications/publication/KeyWorld2017.pd $f$

Ikenberry, G. J. (2009). Liberal Internationalism 3.0: America and the Dilemmas of Liberal World Order. Perspectives on Politics, 71-87. 
International Crisis Group. (2017, October 14). Turkey's PKK Conflict: The Rising Toll. Retrieved from International Crisis Group: http://www.crisisgroup.be/interactives/turkey/\#

İpek, P. (2007). The role of oil and gas in Kazakhstan's foreign. Europe-Asia Studies, 1179-1199.

Ijpek, P. (2017). Oil and intra-state conflict in Iraq and Syria: substate actors and challanges for Turkey's energy secuirty. Middle Eastern Studies, 406-419.

Islamic Republic of Iran Constitution. (2014). Iranian Studies, 159-200. Retrieved 2017, from World Intellectual Property Organization: http://www.wipo.int/edocs/lexdocs/laws/en/ir/ir001en.pdf

Issacharoff, A. (2017, November 28). With victory assured, why is Assad suddenly wary of Iran's embrace? Retrieved from The Times of Israel:

https://www.timesofisrael.com/with-victory-assured-why-is-assad-suddenlywary-of-irans-embrace/

Joobani, H. A., \& Mousavipour, M. (2015). Russia, Turkey, and Iran: Moving Towards Strategic. Strategic Analysis, 141-155.

Kagan, F. W., \& Bucala, P. (2016, March). Iran's Evolving Way of War: How the IRGC Fights in Syria. Retrieved from Critical Threats:

https://www.criticalthreats.org/wp-content/uploads/2016/07/imceimagesIrans_Evolving_Way_of_War_IRGC_in_Syria_FINAL-1.pdf

Kagan, K., Kagan, F. W., Cafarella, J., Zimmerman, K., Zarif, M., McFate, J. L., . . DuryAgri, J. R. (2017, September). Intelligence Estimate and Forecase: The Syrian Theater. Retrieved from Institute for the Study of War: http://www.understandingwar.org/sites/default/files/ISW\%20CTP\%20\%20The\%20Syrian\%20Theater\%20-\%20September\%202017.pdf

Karami, A. (2016, July 19). Rouhani supports Erdogan after coup attempt. Retrieved from Al-Monitor: http://www.al-monitor.com/pulse/ru/originals/2016/07/iranrouhani-support-erdogan-turkey-military-coup.html

Karouny, M., \& Coskun, O. (2015, October 15). Turkey downs drone as Syria launches Aleppo offensive. Retrieved from Reuters: http://www.reuters.com/article/usmideast-crisis-syria-aleppo/turkey-downs-drone-as-syria-launches-aleppooffensive-idUSKCNOSAOMC20151016

Katz, M. N. (2016). Russian-Iranian Relations: Recent Trends and Developments. Russian Analytical Digest, 5-7. Retrieved from https://doi.org/10.3929/ethz-a-010818627 
Kelley, M. B. (2012, October 19). How US Ambassador Chris Stevens May Have Been Linked To Jihadist Rebels In Syria. Retrieved from Business Insider: http://www.businessinsider.com/us-syria-heavy-weapons-jihadists-2012-10

Khaddour, K. (2016, March 14). Strength in Weakness: The Syrian Army's Accidental Resilience. Retrieved from Carnegie Middle East Center: http://carnegiemec.org/2016/03/14/strength-in-weakness-syrian-army-s-accidental-resiliencepub-62968

Khaddour, K., \& Mazur, K. (2013). The Struggle for Syria's Regions. Middle East Report, 211.

Khalidi, A. (2017, October 8). Turkey's Idlib move aimed at Kurds' Mediterranean ambitions. Retrieved from Kurdistan 24: http://www.kurdistan24.net/en/news/61d8ffec-1a62-4e9d-8d44-1351b6c7c8d6

Khomeini, I. (1977, 2017). Islamic Government: Governance of the Jurist. (H. Algar, Trans.) Tehran: The Institute for the Compilation and Publication of Imam Khomeini's Works. Retrieved from http://www.iranchamber.com/history/rkhomeini/books/velayat_faqeeh.pdf

Kinsella, D., Russett, B., \& Starr, H. (2013). World Politics: The Menu for Choice, Tenth Edition. Boston: Wadsworth.

Kozhanov, N. (2016). Russian-Iranian Dialogue After 2012: Turning a New Page? Russian Analytical Digest, 2-4. Retrieved from https://doi.org/10.3929/ethz-a-010818627

Kugler, J., Tammen, R. L., \& Efird, B. (2004). Integrating Theory and Policy: Global Implications of the War in Iraq. International Studies Review, 163-179.

Labott, E., Gaouette, N., \& Roth, R. (2017, March 30). US signals openness to Assad staying put. Retrieved from CNN: http://www.cnn.com/2017/03/30/politics/tillerson-haley-syria-assadturkey/index.html

Lawson, F. H. (2007). Syria's Relations with Iran: Managing the Dilemmas of Alliance. Middle East Journal, 29-47.

Lawson, F. H. (2014). Syria's mutating civil war and its impact on Turkey, Iraq and Iran. International Affairs, 1351-1365.

Legro, J. W., \& Moravcsik, A. (1999). Is Anybody Still a Realist? International Security, 555.

Lemke, D. (1995). Toward a General Understanding of Parity and War. Conflict Management and Peace Science, 143-162. 
Lemke, D. (2008). Power Politics and Wars without States. American Journal of Political Science, 774-786.

Letsch, C. (2015, July 22). Turkey releases bombing suspect details as Twitter temporarily shut down. Retrieved from The Guardian: https://www.theguardian.com/world/2015/jul/22/turkey-blocks-twitter-to-stopbroadcast-of-suruc-bombing-images

Levitt, M. (2005, February). Hezbollah Finances:Funding the Party of God. Retrieved from The Washington Institute for Near East Policy: http://www.washingtoninstitute.org/policy-analysis/view/hezbollah-financesfunding-the-party-of-god

Levs, J. (2012, July 19). Top Syrian officials killed in major blow to al-Assad's regime. Retrieved from CNN: http://www.cnn.com/2012/07/18/world/meast/syriaunrest/index.html

Lewis, B. (1990, September). The Roots of Muslim Rage. Retrieved from The Atlantic: https://www.theatlantic.com/magazine/archive/1990/09/the-roots-of-muslimrage/304643/

Lund, A. (2016, August 24). After Murky Diplomacy, Turkey Intervenes in Syria. Retrieved from Carnegie Middle East Center: http://carnegiemec.org/diwan/64398?lang=en

Lund, A. (2016, January 22). Origins of the Syrian Democratic Forces: A Primer. Retrieved from News Deeply: https://www.newsdeeply.com/syria/articles/2016/01/22/origins-of-the-syriandemocratic-forces-a-primer

Lund, A. (2017, October 17). How Assad's Enemies Gave Up on the Syrian Opposition. Retrieved from The Century Foundation: https://tcf.org/content/report/assadsenemies-gave-syrian-opposition/

Lund, A. (2017, September 7). Opening Soon: The Story of a Syrian-Jordanian Border Crossing. Retrieved from The Century Foundation: https://tcf.org/content/commentary/opening-soon-story-syrian-jordanianborder-crossing/

MacFarquhar, N. (2012, February 11). 2 Security Complex Car Bombings Kill Dozens, Syria Says. Retrieved from The New York Times: http://www.nytimes.com/2012/02/11/world/middleeast/blasts-in-aleppo-syriahoms-violence-said-to-continue.html 
Mandıracı, B. (2016, July 20). Turkey's PKK Conflict: The Death Toll. Retrieved from International Crisis Group: https://www.crisisgroup.org/europe-centralasia/western-europemediterranean/turkey/turkey-s-pkk-conflict-death-toll

Marzouk, L., Angelovski, I., \& Patrucic, M. (2016, July 27). Making a Killing: The 1.2 Billion Euro Arms Pipeline to Middle East - See more at: http://www.balkaninsight.com/en/article/making-a-killing-the-1-2-billion-eurosarms-pipeline-to-middle-east-07-26-2016\#sthash.gYRLnQoS.dpuf. Retrieved from Balkan Arms Trade - Making a Killing:

http://www.balkaninsight.com/en/article/making-a-killing-the-1-2-billion-eurosarms-pipeline-to-middle-east-07-26-2016

Mazzetti, M., Chivers, C., \& Schmitt, E. (2013, June 29). Taking Outsize Role in Syria, Qatar Funnels Arms to Rebels. Retrieved from The New York Times: http://www.nytimes.com/2013/06/30/world/middleeast/sending-missiles-tosyrian-rebels-qatar-muscles-in.html

McDonnell, P. J., Hennigan, W., \& Bulos, N. (2015, September 30). Russia launches airstrikes in Syria amid U.S. concern about targets. Retrieved from Los Angeles Times: http://www.latimes.com/world/europe/la-fg-kremlin-oks-troops20150930-story.html

McElroy, D. (2012, July 18). Assad's brother-in-law and top Syrian officials killed in Damascus suicide bomb. Retrieved from The Telegraph: http://www.telegraph.co.uk/news/worldnews/middleeast/syria/9408321/Assad s-brother-in-law-and-top-Syrian-officials-killed-in-Damascus-suicide-bomb.html

McInnis, M. J. (2016). Iranian Deterrence Strategy and Use of Proxies. Senate Committee on Foreign Relations (p. 8). Statement before the Senate Committee on Foreign Relations: The American Enterprise Institute.

McKirdy, E. (2017, April 13). 8 times Russia blocked a UN Security Council resolution on Syria. Retrieved from CNN: http://www.cnn.com/2017/04/13/middleeast/russiaunsc-syria-resolutions/index.html

Mcleary, P. (2017, May 18). U.S. Bombs Syrian Regime Forces For First Time. Retrieved from Foreign Policy: http://foreignpolicy.com/2017/05/18/u-s-bombs-syrianregime-forces-for-first-time/

Mearsheimer, J. J. (2006). Structural Realism. In T. Dunne, M. Kurki, \& S. Smith (Eds.), International Relations Theories: Discipline and Diversity (pp. 71-88). Oxford: Oxford University Press. 
Moravcsik, A. (1997). Taking Preferences Seriously: A liberal Theory of International Politics. International Organization, 513-553.

Nadimi, F. (2017, December 6). Iran May Double Down on Foreign Militias After Its 'Victory' Against the Islamic State. Retrieved from The Washington Institute for Near East Policy: http://www.washingtoninstitute.org/policy-analysis/view/iranmay-double-down-on-foreign-militias-after-its-victory-against-the-isla

Nordland, R. (2017, January 20). Russia Signs Deal for Syria Bases; Turkey Appears to Accept Assad. Retrieved from The New York Times: https://www.nytimes.com/2017/01/20/world/middleeast/russia-turkey-syriadeal.html

Oktav, Ö. Z. (2015). The Syrian Civil War and Turkey-Syria-Iran Relations. Syria Studies, 119.

Olson, R. (2000). Turkey-Iran Relations, 1997 to 2000: The Kurdish and Islamist Questions. Third World Quarterly, 871-890.

Organski, A. (1958). World Politics. New York: Knopf.

Özcan, N. A., \& Özdamar, Ö. (2010, September 21). Uneasy Neighbors: Turkish-Iranian Relations Since the 1979 Islamic Revolution. Retrieved from Middle East Policy Council: http://www.mepc.org/uneasy-neighbors-turkish-iranian-relations-1979islamic-revolution

Petkova, M. (2017, February 28). Syria's FSA vows to attack government forces in Al Bab. Retrieved from Al Jazeera:

http://www.aljazeera.com/indepth/features/2017/02/syria-fsa-vows-attackgovernment-forces-al-bab-170228103136317.html

Phillips, D. L. (2014, November 9). Research Paper: ISIS-Turkey Links. Retrieved from The Huffington Post: http://www.huffingtonpost.com/david-I-phillips/researchpaper-isis-turke_b_6128950.html

Pramuk, J. (2017, April 6). Trump, Tillerson suggest Assad should be removed, in apparent reversal. Retrieved from CNBC:

http://www.cnbc.com/2017/04/06/trump-tillerson-suggest-assad-should-beremoved-in-apparent-reversal.html

Putin, V. V. (2013, September 11). A Plea for Caution From Russia. Retrieved from The New York TImes: http://www.nytimes.com/2013/09/12/opinion/putin-plea-forcaution-from-russia-on-syria.html?_r=1\& 
Rizzo, J. (2015, July 7). Carter: U.S. trains only 60 Syrian rebels. Retrieved from CNN: http://www.cnn.com/2015/07/07/politics/united-states-training-syrian-rebelsashton-carter/

RT. (2015, November 28). No US airstrikes in Syria since Russia deployed S-400 systems. Retrieved from RT: https://www.rt.com/news/323815-syria-s-400-us-airstrikes/

Rubin, J. (2017, September 19). Trump has accelerated Obama's misguided policy toward Syria. Retrieved from The Washington Post:

https://www.washingtonpost.com/blogs/right-turn/wp/2017/09/19/trump-hasaccelerated-obamas-misguided-policy-toward-syria/?utm_term=.fd8e32f31cea

Sadak, N. (1949). Turkey Faces the Soviets. Foreign Affairs, 449-461.

Sanger, D. E., \& MacFarquhar, N. (2016, August 16). Russia Sends Bombers to Syria Using Base in Iran. Retrieved from The New York Times: https://www.nytimes.com/2016/08/17/world/middleeast/russia-iran-basesyria.html

Satterthwaite, J. C. (1972). The Truman Doctrine: Turkey. Annals of the American Academy of Political and Social Science, 74-84.

Shanghai Cooperation Organization. (2001, June 15). Shanghai Convention on Combating Terrorism, Separatism and Extremism. Retrieved from United Nations High Commission for Refugees: http://www.refworld.org/docid/49f5d9f92.html

Sharafedin, B. (2016, November 22). Death toll among Iran's forces in Syrian war passes 1,000. Retrieved from Reuters: http://www.reuters.com/article/us-mideastcrisis-syria-iran-idUSKBN13H16J

Slackman, M. (2006, March 13). As Syria's Influence in Lebanon Wanes, Iran Moves In. Retrieved from The New York Times: http://www.nytimes.com/2006/03/13/world/middleeast/as-syrias-influence-inlebanon-wanes-iran-moves-in.html

Sogoloff, N. (2017, August 30). Russia's Energy Goals in Syria. Retrieved from Washington Institute for Near East Policy: http://www.washingtoninstitute.org/fikraforum/view/russias-energy-goals-insyria

SPIRI. (2017). SIPRI Arms Transfers Database. Retrieved 2017, from Stockholm International Peace Research Institute: http://www.sipri.org/databases/armstransfers 
Stratfor. (2017, October 6). Russia Wends Its Way Toward an Exit in Syria. Retrieved from Stratfor:

https://www.stratfor.com/sites/default/files/styles/wv_medium/public/syriaconflict-october2017.png?itok=DBYyESfX

Tammen, R. L. (2006). The Impact of Asia on World Politics: China and India Options for the United States. International Studies Review, 563-580.

Tammen, R. L., Lemke, D., Alsharabati, C., Efird, B., Kugler, J., Mark, A. A., \& Organski, A. (2000). Power Transitions: Strategies for the 21st Century. Washington, D.C.: CQ Press.

Tammen, R., Kugler, J., \& Lemke, D. (2011). Power Transition Theory. Retrieved from Trans Research Consortium: transresearchconsortium.com/s/Power-TransitionTheory.pdf

Tarock, A. (1997). Iran and Russia in 'Strategic Alliance'. Third World Quarterly, 207-223.

TASS. (2017, August 25). Russian aircraft deliver around 90,000 strikes against terrorists during Syria operation. Retrieved from TASS: http://tass.com/defense/961957

Tastekin, F. (2016, December 19). Is Turkey recruiting militants evacuated from Aleppo? Retrieved from Al-Monitor: http://www.almonitor.com/pulse/originals/2016/12/turkey-syria-ankara-recruit-militantsfrom-aleppo.html

Tastekin, F. (2017, July 26). Turkey needs new Syria plan as CIA ends rebel support. Retrieved from Al-Monitor: https://www.almonitor.com/pulse/originals/2017/07/turkey-syria-united-states-cia-withdrawalfrom-field.html

The Economist. (2014, April 5). Conscious uncoupling. Retrieved from The Economist: http://www.economist.com/news/briefing/21600111-reducing-europesdependence-russian-gas-possiblebut-it-will-take-time-money-and-sustained

The Ministry of Foreign Affairs Republic of Kazakhstan. (2017, September 15). Kazakhstan welcomes outcomes of the sixth round of the Astana Process on Syria. Retrieved from The Ministry of Foreign Affairs Republic of Kazakhstan: http://www.mfa.kz/en/content-view/kazahstan-privetstvoval-rezultaty-sestogoraunda-astaninskogo-processa-po-sirii

The Shanghai Cooperation Organization. (2017, June 9). The Astana declaration of the Heads of State of the Shanghai Cooperation Organisation. Retrieved from The Shanghai Cooperation Organization: 
file:///C:/Users/Eric/Downloads/The_Astana_declaration_of_the_Heads_of_Stat e_of_the_Shanghai_Cooperation_Organisation.pdf

The Shanghai Cooperation Organization. (n.d.). About SCO. Retrieved May 12, 2017, from The Shanghai Cooperation Organization: http://eng.sectsco.org/about_sco/

The Soufan Group. (2015, November 24). Iran's Forces in Syria. Retrieved from The Soufan Group: http://www.soufangroup.com/tsg-intelbrief-irans-forces-in-syria/

Toksabay, E., \& McDowall, A. (2016, October 20). Turkey bombs Syrian Kurdish militia allied to U.S.-backed force. Retrieved from Reuters: http://www.reuters.com/article/us-mideast-crisis-syria-kurds-idUSKCN12KOER

Tyler, P. E. (2003, December 30). Libya's Atom Bid in Early Phases. Retrieved from The New York Times: http://www.nytimes.com/2003/12/30/world/libya-s-atom-bidin-early-phases.html

U.S. Department of Defense. (n.d.). Operation Inherent Resolve. Retrieved October 22, 2017, from U.S. Department of Defense: https://www.defense.gov/OIR/

U.S. Department of State. (2017, April 12). Remarks With Russian Foreign Minister Sergey Lavrov at a Press Availability. Retrieved from U.S. Department of State: https://www.state.gov/secretary/remarks/2017/04/270136.htm

Ülgen, S. (2017, January 19). Operation Euphrates Shield: Aims and Gains. Retrieved from Carnegie Europe : http://carnegieeurope.eu/2017/01/19/operationeuphrates-shield-aims-and-gains-pub-67754

Ülgen, S., \& Kasapoğlu, C. (2017, January 19). Operation Euphrates Shield: Aims and Gains. Retrieved from Carnegie Europe: http://carnegieeurope.eu/2017/01/19/operation-euphrates-shield-aims-andgains-pub-67754

Umbach, F. (2011). Global Energy Security Challenges: The Impacts of Globalization and Sovereign Control over Energy Resources. Energy security: managing risks, balancing concerns, and developing frameworks (pp. 3-14). New Delhi: KonradAdenauer-Stiftung.

United Nations. (2017, January 6). Security Council- Veto List. Retrieved from United Nations: http://research.un.org/en/docs/sc/quick

United Press International. (2011, July 25). 'Islamic pipeline' seeks Euro gas markets. Retrieved from United Press International: http://www.upi.com/Business_News/Energy-Industry/2011/07/25/Islamicpipeline-seeks-Euro-gas-markets/UPI-13971311588240/ 
Vicente Caro, C. J. (2017, October 19). Moscow's Historical Relationship with Damascus: Why it Matters Now. Retrieved from The Huffington Post: https://www.huffingtonpost.com/carlo-caro/moscows-historicalrelati_b_9065430.html

Yahya, H. (2016, May 10). The PYD \& the PKK: two sides of a coin. Retrieved from The Hill: http://thehill.com/blogs/congress-blog/foreign-policy/279169-the-pyd-thepkk-two-sides-of-a-coin

Yeğinsu, C. (2015, July 22). Suicide Bomber in Suruc Is Said to Be a Turk With Possible Ties to ISIS. Retrieved from The New York Times: https://www.nytimes.com/2015/07/23/world/europe/turkey-surucbombing.html

Yeşilada, B. (2013). EU-Turkey Relations in the 21st Century. New York: Routledge.

Yeşilada, B. A. (2016). The future of Erdoğan and the AKP. Turkish Studies, 19-30.

Yeşilada, B. A., \& Tanrıkulu, O. G. (2016). Regional Power Transition and the Future of Turkey. Uluslararası ilişskiler, 23-46.

Yeşilada, B., Efird, B., \& Noordijk, P. (2006). Competition among Giants: A Look at How Future Enlargement of the European Union Could Affect Global Power Transition . International Studies Review, 607-622 .

Ziegler, C. E. (2013). Central Asia, the Shanghai Cooperation Organization, and American Foreign Policy From Indifference to Engagement. Asian Survey, 484-505. 